\title{
Ruthenium-loaded mesoporous silica as tumor microenvironment-response nano-fenton reactors for precise cancer therapy
}

\author{
Dongdong Sun ${ }^{1 \dagger}$, Zekun Wang ${ }^{1 \dagger}$, Pu Zhang ${ }^{2+}$, Chenyang Yin ${ }^{1}$, Jingyuan Wang ${ }^{1}$, Yu Sun ${ }^{1}$, Ying Chen , \\ Weiyun Wang ${ }^{1}$, Baoliang Sun ${ }^{3}$ and Cundong Fan ${ }^{3 *}$
}

\begin{abstract}
Background: Nano-Fenton reactors as novel strategy to selectively convert hydrogen peroxide $\left(\mathrm{H}_{2} \mathrm{O}_{2}\right)$ into active hydroxyl radicals in tumor microenvironment for cancer therapy had attracted much attention. However, side effects and low efficiency remain the main drawbacks for cancer precise therapy.

Results: Here, ruthenium-loaded palmitoyl ascorbate (PA)-modified mesoporous silica (Ru@SiO_-PA) was successfully fabricated and characterized. The results indicated that $\mathrm{Ru@SiO} 2-\mathrm{PA}$ under pH6.0 environment displayed enhanced growth inhibition against human cancer cells than that of pH7.4, which indicated the super selectivity between cancer cells and normal cells. Ru@SiO 2 -PA also induced enhanced cancer cells apoptosis, followed by caspase-3 activation and cytochrome-c release. Mechanism investigation revealed that Ru@SiO $2-P A$ caused enhanced generation of superoxide anion, which subsequently triggered DNA damage and dysfunction of MAPKs and PI3K/AKT pathways. Moreover, Ru@SiO 2 -PA effectively inhibited tumor spheroids and tumor xenografts growth in vivo by induction of apoptosis. The real-time imaging by monitoring Ru fluorescence in vitro and in vivo revealed that Ru@SiO 2 -PA mainly accumulated in cell nucleus and tumor xenografts. Importantly, Ru@SiO 2 -PA showed no side effects in vivo, predicting the safety and potential application in clinic.
\end{abstract}

Conclusions: Our findings validated the rational design that Ru@SiO 2 -PA can act as novel tumor microenvironmentresponse nano-Fenton reactors for cancer precise therapy.

Keywords: Tumor microenvironment, Mesoporous silica, Nano-Fenton reactors, Cancer precise therapy

\section{Introduction}

Normal cells usually maintain a redox balance between the generation of reactive oxygen species (ROS) and ROS elimination [1]. Disorder of redox homeostasis may result in damage to biological molecules, leading to

\footnotetext{
*Correspondence: tcdfan66@163.com

†Dongdong Sun, Zekun Wang and Pu Zhang contributed equally to this work

${ }^{3}$ Department of Neurology, Second Affiliated Hospital; Key Lab of Cerebral Microcirculation in Universities of Shandong, Shandong First Medical University \& Shandong Academy of Medical Sciences, Taian 271000, Shandong, China

Full list of author information is available at the end of the article
}

inflammation and even tumorigenesis [2, 3]. However, cancer cells usually show high level oxidative stress compared with that of normal tissues, which plays key role in driving tumor proliferation and tumor development $[4,5]$. Ironically, cancer cells are fragile to overproduced ROS because of the deficiency of ROS-depleting enzyme systems in tumor regions [6-8]. Overproduction of ROS can damage kinds of biological molecules and induce oxidative damage, which is accepted as an effective way for cancer therapy [2,3]. Accumulated studies confirmed that ROS-mediated oxidative damage and apoptotic cell death of cancer cells contribute to chemotherapy, radiotherapy, and photodynamic of tumors [9-11]. Therefore, 
design of anticancer drugs with amplified oxidative stress in tumor regions to preferentially kill cancer cells has been accepted as novel strategy for precise cancer therapy, named as oxidation therapy.

Oxidation therapy refers to delivery of exogenous ROS or ROS-generating agents to tumor regions, or inhibition of ROS-depleting enzymes [7, 12], and now a large number of ROS-generating molecular have been found for nano-Fenton reactors to increase the ROS level in tumor regions [13-15]. Nano-Fenton reactor carrying $\mathrm{H}_{2} \mathrm{O}_{2}$-generating agent and catalyst can convert $\mathrm{H}_{2} \mathrm{O}_{2}$ into high cytotoxic hydroxyl radicals in tumor acidic microenvironment to selectively kill cancer cells and has been well studies [16-19]. High metabolic level of tumor tissue mainly depends on anaerobic glycolysis to provide energy, which produces a large amount of lactobionic acid [20]. In order to maintain a neutral cytoplasmic environment and avoid acidosis, tumor cells can produce a large amount of $\mathrm{H}^{+}$and pump them out of the cell by ion exchanger, which results in the acidic extracellular tumor microenvironment [21]. Accumulated studies have confirmed that vitamin $\mathrm{C}$ or its derivate, such as palmitoyl ascorbate (PA), usually displays antioxidant activity at physiological concentration. However, vitamin $\mathrm{C}$ and its derivate usually act as a prooxidant therapeutic agent at pharmacologic concentration in therapy of cancer and infections [22]. Vitamin C (VC) and its derivates can be oxidized by a metalloprotein in tumor acidic microenvironment and yield tumoricidal $\mathrm{H}_{2} \mathrm{O}_{2}$, which is often employed as $\mathrm{H}_{2} \mathrm{O}_{2}$-generating agent in Nano-Fenton reactors [23-25]. Ferrocene as the catalyst of Nano-Fenton reactors undergoes oxidation to produce $\mathrm{Fe}^{2+}$, which can convert $\mathrm{H}_{2} \mathrm{O}_{2}$ into hydroxyl radicals [10, 26, 27]. So far, kinds of nano-Fenton reactors have been designed and achieved promising outcomes in combating human cancer. For instance, Ma et al.explored an enhanced cisplatin chemotherapy by iron oxide nanocarrier-mediated generation of highly toxic ROS in tumor regions through Fenton reaction [28]. Yin et al. reported that PEG-modified PA-integrated hybrid micelles showed amplified tumor oxidative stress for cancer oxidation therapy [29]. Kwon et al. constructed $\mathrm{H}_{2} \mathrm{O}_{2}$-generating benzoyloxycinnamaldehyde (BCA) and ferrocene catalyst, and the result indicated that PolyCAFe micelles can act as a new nano-fenton reactors with amplified oxidative stress in tumor regions for cancer therapy [18]. However, side effects and low efficiency remain the drawbacks in limiting its development. In the present study, rutheniumloaded palmitoyl ascorbate (PA)-modified mesoporous silica $\left(\mathrm{Ru} @ \mathrm{SiO}_{2}-\mathrm{PA}\right)$ as a novel nano-Fenton reactor was successfully fabricated and characterized. $\mathrm{H}_{2} \mathrm{O}_{2}$ was generated in the tumor acidic microenvironment in the presence of $\mathrm{PA}$, and $\mathrm{Ru}^{2+}$ as the catalyst can catalyze
$\mathrm{H}_{2} \mathrm{O}_{2}$ into high active hydroxyl radicals [23]. The results revealed that $\mathrm{Ru} @ \mathrm{SiO}_{2}-\mathrm{PA}$ showed selectively growth inhibition against cancer cells in vitro and in vivo by triggering ROS-mediated oxidative stress and regulating multiple signal pathways. Meanwhile, $\mathrm{Ru} @ \mathrm{SiO}_{2}-\mathrm{PA}$ displayed less side effects and good biocompatibility in vitro and in vivo. Our findings validated the rational design that ruthenium-loaded PA-modified mesoporous silica $\left(\mathrm{Ru} @ \mathrm{SiO}_{2}-\mathrm{PA}\right)$ can act as novel tumor microenvironment-response nano-Fenton reactors for cancer precise therapy.

\section{Experimental section \\ Chemicals}

Tris (2,2-Bipyridyl) Ruthenium (II) Chloride Hexahydrate, Ethyl orthosilicate (TEOS), cetyltrimethylammonium chloride (CTAC), aminopropyltriethylaminosilane (APTES), ammonium nitrate and L-ascorbyl palmitate (PA) were all purchased from Aladdin (Shnaghai, China). Hiazolyl blue tetrazolium bromide (MTT), Dihydroethidium (DHE) probes, glutathione (GSH), and other agents were all purchased from Sigma-Aldrich. BCA kit, Giemsa staining and Annexin V was purchased from Beyotime (Beijing, China). Dulbecco's modified eagle medium (DMEM), fetal bovine serum (FBS) and penicillin-streptomycin was purchased from Invitrogen. All antibodies and inhibitors used in this study were bought from Cell Signaling Technology (CST, Beverly, MA, USA). All solvents were obtained with high performance liquid chromatography (HPLC) grade. Ultrapure MilliQ water (18.25 MW) was used in all experiments.

\section{Synthesis of Ru@SiO $-P A$}

Briefly, $10 \mathrm{mg}$ of ruthenium complex was dissolved in a mixed solution of $50 \mathrm{ml}$ of deionized water and $60 \mathrm{ml}$ of absolute ethanol. Under constant stirring, $3.5 \mathrm{ml}$ of ammonia water and $0.12 \mathrm{~g}$ of CTAC were added to the reaction system. After stirring for $5 \mathrm{~min}, 200 \mu \mathrm{l}$ APTES was added, and then $1 \mathrm{ml}$ of TEOS $(0.25 \mathrm{ml} / \mathrm{min})$ was added dropwise. After stirring for $6 \mathrm{~h}$, obtain the precipitate by centrifugation $(10,000 \mathrm{rpm}, 10 \mathrm{~min})$, and washed three times with absolute ethanol and pure water, respectively. The pellet was washed three times with ethanol and water and then dispersed in a solution of $\mathrm{NH}_{4} \mathrm{NO}_{3}$ $(50 \mathrm{ml}, 5 \mathrm{mg} / \mathrm{ml}$ ) in ethanol, and the mixture was stirred under reflux at $60{ }^{\circ} \mathrm{C}$ for $5 \mathrm{~h}$ to remove the CTAC template by an ion exchange method. The product was obtained by centrifugation (10,000 rpm, $10 \mathrm{~min})$, washed three times with methanol and pure water, and then dried in a vacuum environment at $40^{\circ} \mathrm{C}$ for $24 \mathrm{~h}$ to obtain Ru@ $\mathrm{SiO}_{2}$ shell-core nanospheres. 


\section{Loading and in vitro release of $P A$}

$\mathrm{Ru} @ \mathrm{SiO}_{2}$ dry powder $(5 \mathrm{mg})$ was added to $10 \mathrm{ml} \mathrm{PA}$ ethanol solution $(2 \mathrm{mg} / \mathrm{ml})$, and was stirred for $24 \mathrm{~h}$ at room temperature. The excess PA was removed by centrifugation (10,000 rpm, $10 \mathrm{~min})$, and washed three times with anhydrous ethanol, and dried under vacuum to obtain $\mathrm{Ru} @ \mathrm{SiO}_{2}-\mathrm{PA}$ nanospheres. All supernatants were collected and appropriately diluted, and the absorbance was measured at $246 \mathrm{~nm}$ by a UV-visible spectrophotometer to calculate the amount of PA payload in $\mathrm{Ru} @ \mathrm{SiO}_{2}$ nanospheres. Drug loading of the $\mathrm{Ru} @ \mathrm{SiO}_{2}-\mathrm{PA}=$ (weight of PA loaded into $\mathrm{Ru} @ \mathrm{SiO}_{2}$ ) / (total weight of $\mathrm{Ru} @ \mathrm{SiO}_{2}-\mathrm{PA}$ ). The in vitro release of PA from $\mathrm{Ru} @ \mathrm{mSiO}_{2}$ was investigated using the previously reported dialysis method. In short, $1 \mathrm{ml}$ of $\mathrm{Ru} @ \mathrm{SiO}_{2}-\mathrm{PA}(1 \mathrm{mg} / \mathrm{ml})$ was added to a dialysis bag (molecular cutoff of $10 \mathrm{KD}$ ) and placed in $19 \mathrm{ml}$ of PBS containing $0.1 \%$ Tween $80(\mathrm{pH}=7.4 / 6.0)$, collect and replace the release medium every $2 \mathrm{~h}$, and quantify the PA in the medium by an ultraviolet spectrophotometer. In addition, PA was dissolved in $0.1 \%$ Tween 80 in PBS $(\mathrm{pH}=7.4)$, and the release of PA solution was assessed based to the above method to determine the effect of the dialysis bags on the diffusion of chlorogenic acid molecules. All experiments were repeated at least 3 times.

\section{Characterization of $\mathrm{Ru}_{\mathrm{SiO}}-\mathrm{PA}$}

The shape and surface characteristics of $\mathrm{Ru} @ \mathrm{SiO}_{2}-\mathrm{PA}$ nanospheres were analyzed by transmission electron microscope (TEM; HT7700; Hitachi, Japan) and scanning electron microscope (SEM; S-4800; Hitachi, Japan). Energy dispersive X-ray spectrometer (EDS, Oxford, $\mathrm{X}$-Max N 150) is used for elemental analysis. The dynamic light scattering (DLS) and zeta potentials measurements were used for characterization of NPs optical properties and sizes on a Zeta-PALS (Brookhaven) instrument. X-ray photoelectron spectroscopy (XPS) was used to study the elemental composition and valence of $\mathrm{Ru} @ \mathrm{mSiO}_{2}$-PA. X-ray diffraction (XRD; XRD-6100; Shimadzu, Japan) is used to study the crystal structure of nanospheres. The UV-Vis spectrum (Scinco Co., Korea) and Fourier transform infrared spectrum (FTIR; Nicoletteis50; Thermo Fisher Science, USA) were used to determine the synthesis of nanospheres.

$\mathrm{H}_{2} \mathrm{O}_{2}$ production of PA in Dulbecco's modified Eagle's medium (DMEM) with 10\% FBS was measured using a dissolved oxygen meter in the presence of catalase. Briefly, PA at final concentrations of 3, 6, 12 or $24 \mu \mathrm{g} / \mathrm{ml}$ was added to DMEM containing 10\% FBS and incubated at room temperature. At predetermined time intervals, $10 \mathrm{ml}$ aliquots of the culture medium were removed, then $200 \mu \mathrm{l}$ of 1000 units of catalase solution were added, and an $\mathrm{O}_{2}$ sensor was used to evaluate the pro-oxidation of PA.

$\mathrm{OH}$ radicals were detected using disodium terephthalate as a capture agent. Briefly, $200 \mu \mathrm{l}$ of disodium terephthalate solution $(50 \mathrm{mM})$ and $200 \mu \mathrm{l}$ of PBS, PA (6 $\mu \mathrm{g} / \mathrm{ml}), \mathrm{Fe}_{3} \mathrm{O}_{4} @ \mathrm{mSiO}_{2}(14 \mu \mathrm{g} / \mathrm{ml})$ or $\mathrm{Fe}_{3} \mathrm{O}_{4} @ \mathrm{mSiO}_{2}-$ PA $(20 \mu \mathrm{g} / \mathrm{ml})$ were added to1.6 $\mathrm{ml}$ of DMEM containing $10 \%$ FBS. The solution was subjected to fluorescence tracing using a fluorescence spectrometer $(E x=310 \mathrm{~nm}$, $E m=425 \mathrm{~nm})$.

\section{Cell culture and cell viability}

HepG2 human hepatocarcinoma cells, MCF-7 human breast carcinoma cells, and SGC-7901 human gastric carcinoma cells were obtained from ATCC company and cultured with DMEM medium supplemented with $10 \%$ fetal bovine serum and penicillin (100 units $/ \mathrm{ml}$ ), and streptomycin (50 units $/ \mathrm{ml}$ ) at $37{ }^{\circ} \mathrm{C}$ under $5 \% \mathrm{CO}_{2}$ atmosphere. HUVECs human umbilical vein endothelial cells were cultured with endothelial culture medium and were employed as the normal cells. Medium was adjusted into $\mathrm{pH} 6.0$ by $\mathrm{HCl}$ to stimulate the acidic tumor microenvironment. The normal medium ( $\mathrm{pH} 7.4$ ) was set as the neutral microenvironment. Cells $\left(10^{4}\right.$ cells/well) were seeded in 96-well plate and cultured under pH6.0 and pH7.4 medium for $24 \mathrm{~h}$. Cells were treated with 2.5$20 \mu \mathrm{g} / \mathrm{ml} \mathrm{Ru} @ \mathrm{SiO}_{2}$ or $\mathrm{Ru} @ \mathrm{SiO}_{2}$-PA for 72 h. Cells viability was detected by MTT assay. All experiments were repeated at least 3 times. Cells viability was expressed as percentage of control (as 100\%).

\section{Detection of cells apoptosis}

SGC-7901 cells seeded in 2-cm culture plate were exposed to $2.5-20 \mu \mathrm{g} / \mathrm{ml} \mathrm{Ru} @ \mathrm{SiO}_{2}$ or $\mathrm{Ru} @ \mathrm{SiO}_{2}-\mathrm{PA}$ for $12 \mathrm{~h}$. Cells after treatment were incubated with annexin $\mathrm{V}$ probe for $15 \mathrm{~min}$ in darkness. Then cells were washed with PBS, and the early cells apoptosis was imaged by a fluorescent microscope (magnification, 200×).

\section{Measurement of caspase- 3 activity}

SGC-7901 cells seeded in 9-cm culture plate were exposed to 2.5-20 $\mu \mathrm{g} / \mathrm{ml} \mathrm{Ru} @ \mathrm{SiO}_{2}$ or $\mathrm{Ru} @ \mathrm{SiO}_{2}$-PA for $72 \mathrm{~h}$. Cells after treatment were washed, collected by centrifugation, and the total protein was extracted and quantified by BCA kit. $100 \mu \mathrm{g} /$ well of protein was added into 96-well plate and incubated with specific Ac-DEVDAMC substrate for $40 \mathrm{~min}$ in darkness. The caspase-3 activity was detected by fluorescent microreader with the 380 excitation and $440 \mathrm{~nm}$ emission.

\section{Western blotting}

SGC-7901 cells seeded in 9-cm culture plate were exposed to 2.5-20 $\mu \mathrm{g} / \mathrm{ml} \mathrm{Ru@SiO}{ }_{2}$ or $\mathrm{Ru} @ \mathrm{SiO}_{2}-\mathrm{PA}$ for 
$72 \mathrm{~h}$. Cells after treatment were washed, collected by centrifugation, and the total protein was extracted and quantified by BCA kit. $40 \mu \mathrm{g} /$ lane protein was loaded and separated by electrophoresis. Then, protein was transferred onto a nitrocellulose membrane, and blocked by $5 \%$ non-fat milk in TBS buffer for $1 \mathrm{~h}$. Then, the membranes were washed and incubated with primary antibodies overnight at $4{ }^{\circ} \mathrm{C}$. Membranes subsequently were washed and incubated specific second antibodies for $2 \mathrm{~h}$ at room temperature. Then, the membranes were washed and the target proteins were detected on by chemiluminescence reagent under a Bio-Rad image system.

\section{Inhibitory effects on tumor spheroids}

$\mathrm{Ru} @ \mathrm{SiO}_{2}$-PA-induced anticancer efficiency was also evaluated in 3-dimensional (3D) multicellular tumor spheroids as described previously [18]. Briefly, SGC-7901 cells $\left(6 \times 10^{5}\right.$ cells/well $)$ were seeded in ultra-low attachment 6 -well plate and cultured for 2 days. Then, tumor spheroids were treated with 2.5-20 $\mu \mathrm{g} / \mathrm{ml} \mathrm{Ru} @ \mathrm{SiO}_{2}$ or $\mathrm{Ru} @$ $\mathrm{SiO}_{2}$-PA for $72 \mathrm{~h}$. After incubation, the tumor spheroids were observed by a fluorescent microscope (magnification, $100 \times)$. The quantitative analysis of tumor spheroids volume was conducted to evaluate $\mathrm{Ru} @ \mathrm{SiO}_{2}-\mathrm{PA}$-induced anticancer efficiency against SGC-7901 cells. All experiments were repeated at least 3 times.

\section{Examination of oxidative stress}

The status of oxidative stress in SGC-7901 cells was monitored by measuring the accumulation of superoxide anion with DHE probe. Briefly, SGC-7901 cells seeded in 2-cm plate were pre-loaded with $10 \mu \mathrm{M}$ DHE probe for $15 \mathrm{~min}$ in darkness, and cells were washed and exposed to $10 \mu \mathrm{g} / \mathrm{ml} \mathrm{Ru@SiO}$ or $\mathrm{Ru} @ \mathrm{SiO}_{2}$-PA for 10-120 min. Then, the real-time generation of superoxide anion (red fluorescence) was imaged under a fluorescent microscope (magnification, $100 \times$ ). The real-time generation of superoxide anion was also examined in tumor spheroids. Briefly, SGC-7901 cells $\left(6 \times 10^{5}\right.$ cells/well $)$ were seeded in ultra-low attachment 6 -well plate and cultured for 5 days. Then, SGC-7901 tumor spheroids were pre-incubated with DHE probe and washed, and treated $20 \mu \mathrm{g} / \mathrm{ml} \mathrm{Ru} @$ $\mathrm{SiO}_{2}$ or $\mathrm{Ru@SiO}-\mathrm{PA}$ for 10-120 min. The real-time generation of superoxide anion was imaged under a fluorescent microscope (magnification, $100 \times$ ).

\section{Anticancer activity in vivo}

$\mathrm{Ru} @ \mathrm{SiO}_{2}$-PA-induced anticancer activity in vivo was examined in nude mice bearing SGC-7901 tumor xenografts. Briefly, SGC-7901 cells $\left(10^{7}\right.$ cells $)$ were subcutaneously injected into the nude mice. After 7-days tumor growth, mice were given 2.5 and $5 \mathrm{mg} / \mathrm{kg} \mathrm{Ru} @ \mathrm{SiO}_{2}-\mathrm{PA}$ by tail intravenous injection every other day for 21 days.
The real-time tumors volume change was monitored. After treatment, nude mice bearing SGC-7901 tumor xenografts were imaged, and the final tumors were collected and imaged. The tumors weight were measured and quantified. Part of tumor tissue was used for western blot analysis.

\section{Biodistribution in vitro and in vivo}

Biodistribution $\mathrm{Ru} @ \mathrm{SiO}_{2}-\mathrm{PA}$ was firstly examined in vitro. Briefly, SGC-7901 cells seeded in 2-cm plate were treated with $2.5 \mu \mathrm{g} / \mathrm{ml} \mathrm{Ru} @ \mathrm{SiO}_{2}-\mathrm{PA}$ for 3-12 h. The real-time biodistribution of $\mathrm{Ru} @ \mathrm{SiO}_{2}-\mathrm{PA}$ in vitro were imaged by measure the $\mathrm{Ru}$ fluorescence (magnification, $200 \times)$. The in vivo biodistribution of $\mathrm{Ru} @ \mathrm{SiO}_{2}-\mathrm{PA}$ was monitored by real-time imaging in nude mice. Briefly, $\mathrm{Ru} @ \mathrm{SiO}_{2}$-PA (10 mg/kg) was given by tail vein injection, and real-time imaging of $\mathrm{Ru}$ fluorescence at 1, 2 and $3 \mathrm{~h}$ was detected by in vivo fluorescence imaging system (Caliper Perkin Elmer).

\section{Analysis of pathology and hematology}

Safety of $\mathrm{Ru} @ \mathrm{SiO}_{2}-\mathrm{PA}$ in vivo was evaluated in nude mice by analysis of pathology and hematology. Briefly, Nude mice after treatment were all given euthanasia, and main organs (heart, liver, spleen, lung, kidney and brain) were collected, cut into $4 \mu \mathrm{M}$ slices and stained by H\&E for histopathological examination under a microscope (magnification, $100 \times$ ). Moreover, blood from nude mice or nude mice bearing SGC-7901 tumor xenografts was collected, and blood glucose (GLU), cholesterol (CHOL), serum creatinine (CREA), albumen (ALB), globulin (GLB) and lactate dehydrogenase (LDH) were all detected by ELISA methods to evaluate the health of kidney, liver and heart. All experiments were repeated at least 3 times. Health nude mice without tumor xenografts were used as the positive control group. Nude mice with tumor xenografts were used as the blank.

\section{Statistical analysis}

All experiments were done at least for three times. Data were expressed as mean $\pm \mathrm{SD}$. Statistical analysis was assayed by SPSS 13.0 (SPSS, Inc.). Statistical significance was analyzed by one-way ANOVA followed by a Dunnett's or Tukey's post-hoc test. ${ }^{*} \mathrm{P}<0.05$ vs. blank, $*: \mathrm{P}<0.01$ vs. blank. Bars with different letters indicate the Statistical significance at $\mathrm{P}<0.05$ level.

\section{Results and discussion}

\section{Synthesis and characterization of Ru@SiO $2-\mathrm{PA}$}

SEM and TEM image showed that relatively homogeneous nanostructures had been successfully prepared (Fig. 1a, b). As shown in Fig. 1c, $\mathrm{Ru} @ \mathrm{SiO}_{2}$-PA has a uniform size, and the average diameter of the nanospheres 

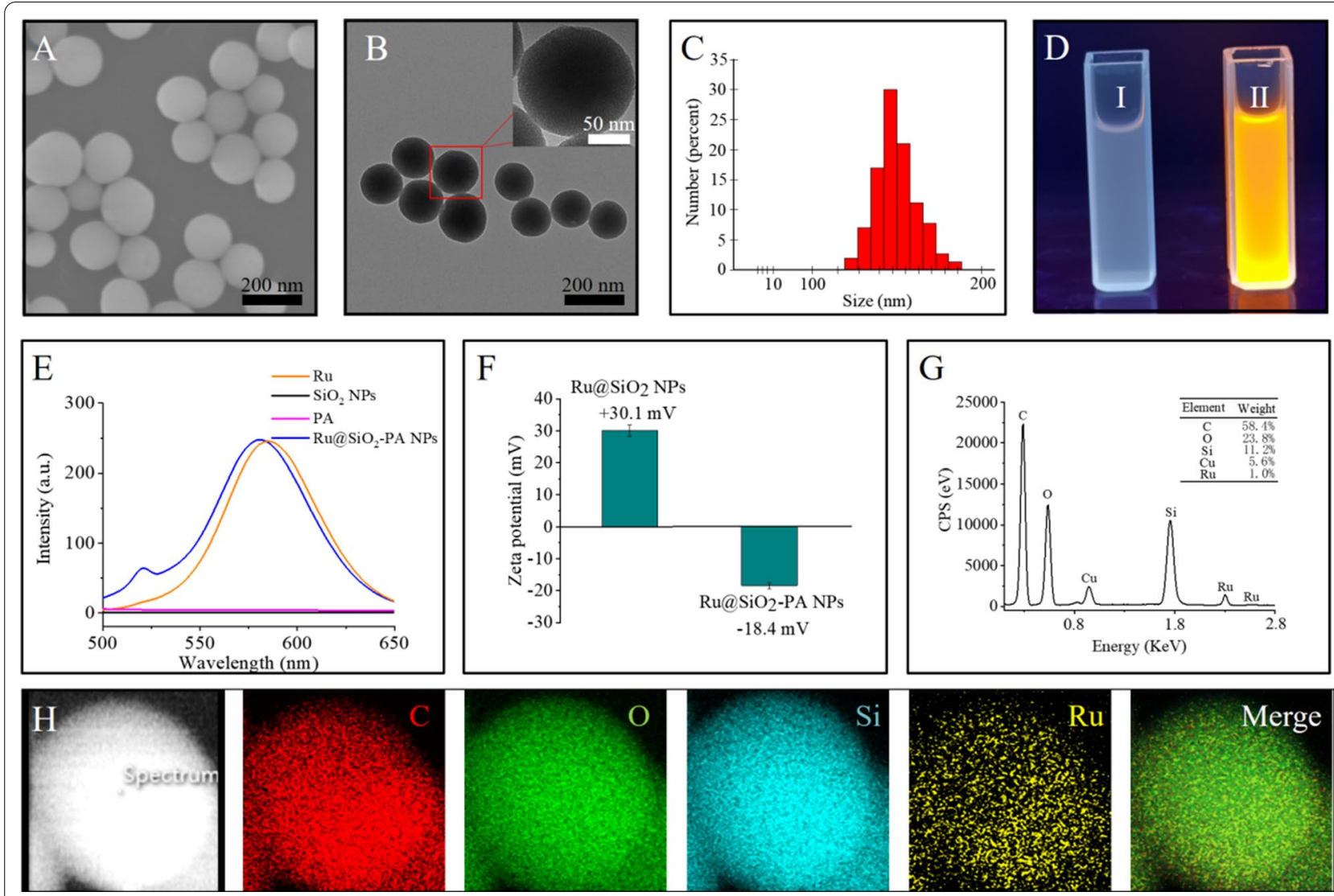

Fig. 1 Synthesis and morphology of Ru@SiO 2 -PA. a SEM images and TEM images $\mathbf{b}$ of Ru@SiO 2 -PA. c Hydrodynamic diameters and distributions

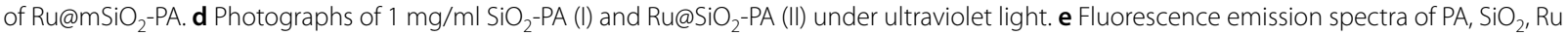

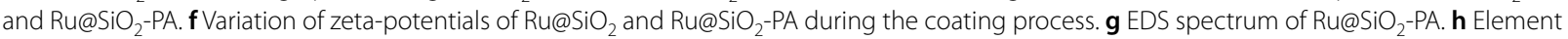
mapping of $\mathrm{Ru} @ \mathrm{SiO}_{2}-\mathrm{PA}$

was $140 \pm 15 \mathrm{~nm}$. As shown in Fig. 1d, the synthesized $\mathrm{Ru} @ \mathrm{SiO}_{2}$-PA could be uniformly dispersed in water and exhibited fluorescent properties under ultraviolet light, while $\mathrm{PA}$ and $\mathrm{SiO}_{2}$-PA did not exhibit any fluorescent properties (Fig. 1e). The zeta potential of the $\mathrm{Ru} @ \mathrm{SiO}_{2}$ dissolved in PBS was about+30.1 mV. Those of the Ru@ $\mathrm{SiO}_{2}$ coated with PA turned to be $-18.4 \mathrm{mV}$ (Fig. 1f). The elemental mapping images confirm that $\mathrm{C}, \mathrm{O}, \mathrm{Si}$ and $\mathrm{Ru}$ elements were distributed in the $\mathrm{Ru} @ \mathrm{SiO}_{2}-\mathrm{PA}$ homogeneously (Fig. 1g, h).

To confirm the formation of $\mathrm{SiO}_{2}-\mathrm{PA}, \mathrm{UV}$-vis Spectra assays were performed. Figure 2a shows PA has characteristic absorption peaks at $246 \mathrm{~nm}$. Similar results were observed for $\mathrm{SiO}_{2}-\mathrm{PA}$. The FTIR patterns of $\mathrm{SiO}_{2}$ show typical $\mathrm{Si}-\mathrm{O}-\mathrm{Si}$ tensile vibration peaks at $1070 \mathrm{~cm}^{-1}$ and $960 \mathrm{~cm}^{-1}$. PA showed stretching vibration peaks of $-\mathrm{CH}_{2}$ at $2851 \mathrm{~cm}^{-1}$ and $2917 \mathrm{~cm}^{-1}$, similarly appeared in $\mathrm{SiO}_{2}-\mathrm{PA}$ (Fig. 2b). The crystal structure of $\mathrm{Ru} @ \mathrm{SiO}_{2}$ and $\mathrm{Ru} @ \mathrm{SiO}_{2}-\mathrm{PA}$ was examined by XRD pattern (Fig. 2c). The two show a high degree of similarity in the spectrum, and there are obvious dispersion peaks at $20^{\circ}-25^{\circ}$ of $2 \theta$, which was the standard characteristic peak of the typical amorphous structure $\mathrm{SiO}_{2}$. These results indicate that $\mathrm{Ru} @ \mathrm{SiO}_{2}-\mathrm{PA}$ was successfully synthesized. XPS analysis was used to study the surface composition and chemical bond state, which can provide information on the interaction between $\mathrm{SiO}_{2}$ and $\mathrm{Ru}$. Figure $2 \mathrm{~d}$ shows the $\mathrm{Si} 2 \mathrm{p}$ spectrum, the peak at $102.6 \mathrm{eV}$ was consistent with the previously reported binding energy of silica. Figure $2 \mathrm{e}$ shows the Ru3p spectrum, the two peaks of Ru3p $\mathrm{p}_{1 / 3}$ and Ru3 $\mathrm{p}_{2 / 3}$ are located at $484.5 \mathrm{eV}$ and $462.4 \mathrm{eV}$, respectively. According to the standard curve of PA, the drug loading of $\mathrm{Ru} @ \mathrm{SiO}_{2}-\mathrm{PA}$ is calculated to be $30.7 \%$. As shown in Fig. 2f, the cumulative release amount of the PA at $\mathrm{pH}=7.4$ was quite small within $24 \mathrm{~h}$. However, due to the increased solubility of PA under acidic conditions, the release rate of the drug becomes faster at $\mathrm{pH}=6.0$, and the cumulative release of the drug was as high as $60.8 \%$. This $\mathrm{pH}$-dependent release profile was more beneficial for tumor therapy. Due to the oxidation reaction between $\mathrm{PA}$ and certain metal ion-containing proteins, $\mathrm{H}_{2} \mathrm{O}_{2}$ is effectively produced in a PA concentration-dependent 


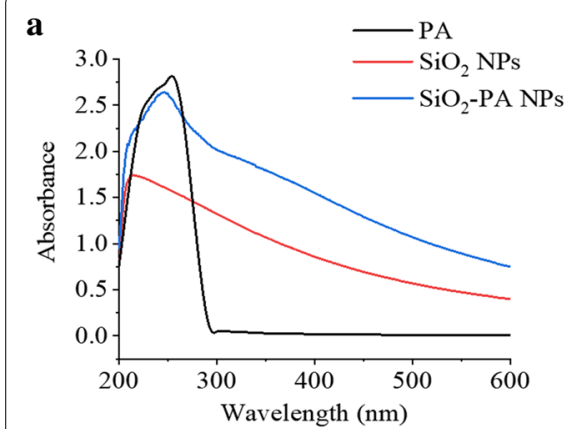

d

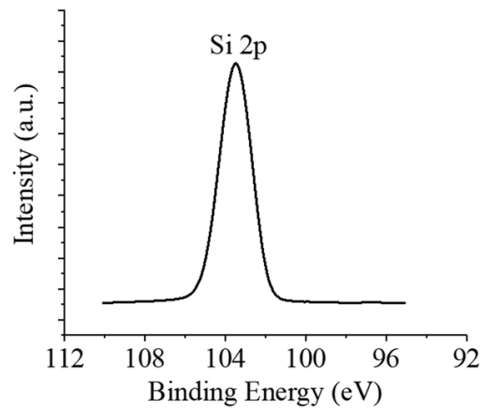

g

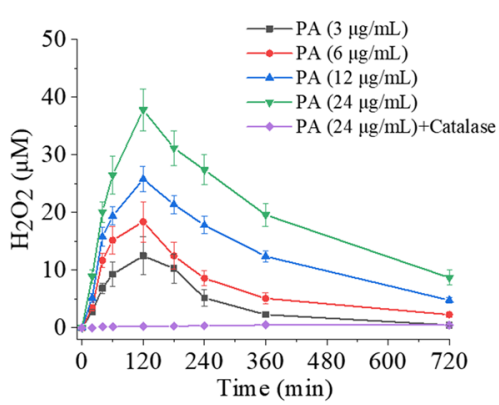

b

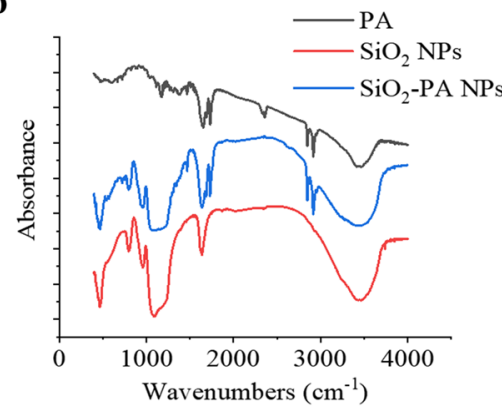

e

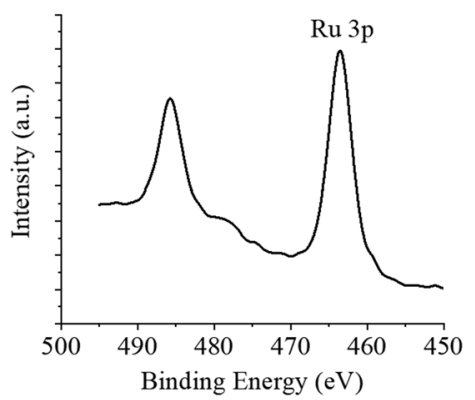

h

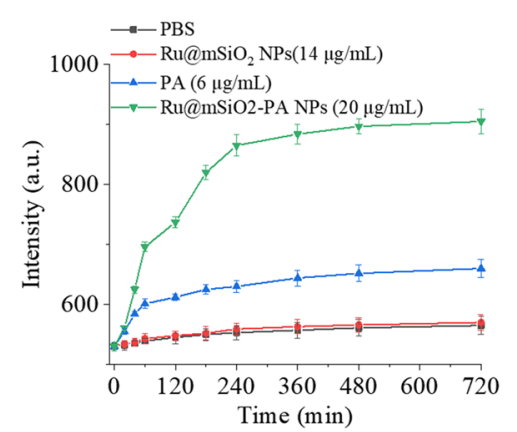

c

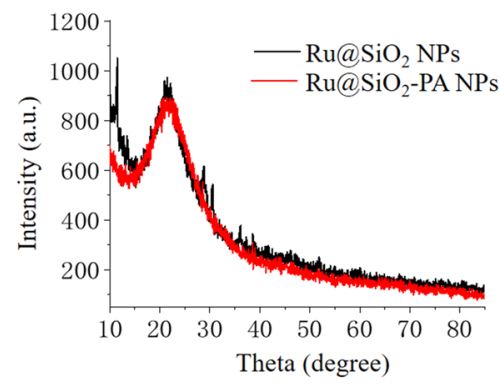

f

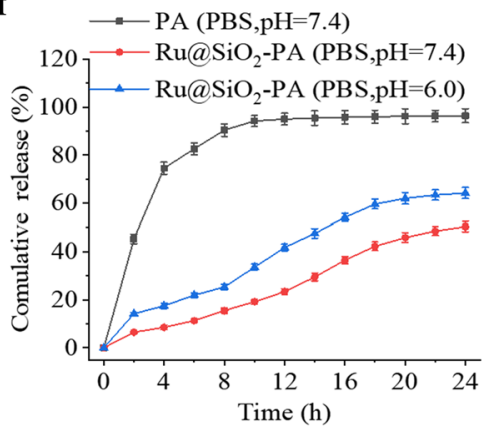

i

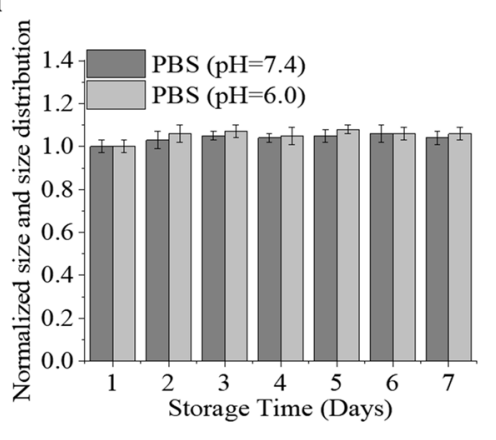

Fig. 2 Characterization of Ru@SiO $\mathrm{S}_{2}-\mathrm{PA}$. a UV-vis absorption spectra of $\mathrm{PA}, \mathrm{SiO}_{2}$ and $\mathrm{SiO}_{2}-\mathrm{PA}$. b FTIR spectrum of PA, c XRD spectrum of Ru@SiO $-\mathrm{PA}$. $\mathrm{SiO}_{2}$ and $\mathrm{SiO}_{2}-\mathrm{PA} . \mathrm{Si}^{2 \mathrm{P}} \mathbf{d}$ and $\mathrm{Ru}^{3 \mathrm{P}}$ e XPS spectrum of $\mathrm{Ru} @ \mathrm{SiO}_{2}-\mathrm{PA}$. $\mathbf{f}$ Relative PA release of $\mathrm{Ru} @ \mathrm{SiO}_{2}-\mathrm{PA}$ at $\mathrm{pH}=7.4 / 6$. g Cumulative $\mathrm{H}_{2} \mathrm{O}_{2}$ production in DMEM medium (10\% serum) in the presence of PA. $\mathbf{h}$ Fluorescence intensity change of 2-hydroxyterephthalic acid as a function of time after incubation with PA (6 $\mu \mathrm{g} / \mathrm{ml}), \mathrm{Fe}_{3} \mathrm{O}_{4} @ \mathrm{mSiO}_{2}(14 \mu \mathrm{g} / \mathrm{ml})$, or $\mathrm{Fe}_{3} \mathrm{O}_{4} @ \mathrm{mSiO}_{2}-\mathrm{PA}(20 \mu \mathrm{g} / \mathrm{ml})$ in 10\% serum-containing medium. (I) The relative size

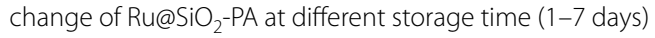

manner. At the test concentration, the concentration of $\mathrm{H}_{2} \mathrm{O}_{2}$ reached its peak in about 120 min (Fig. 2g). The increased concentration provides the necessary $\mathrm{H}_{2} \mathrm{O}_{2}$ for the Fenton reaction to produce highly active $\bullet \mathrm{OH}$ radicals. In addition, we also evaluated the production of $\mathrm{OH}$ radicals in vitro. As shown in Fig. 2h, the fluorescence intensity of only $\mathrm{Ru} @ \mathrm{SiO}_{2}$ and PBS remained almost constant. In sharp contrast, the fluorescence intensity of $\mathrm{Ru} @ \mathrm{SiO}_{2}-\mathrm{PA}$ increases rapidly at the equivalent concentration. In conclusion, the results confirmed that PA can produce $\mathrm{H}_{2} \mathrm{O}_{2}$ in serum-containing DMEM medium, and catalyze the production of a large number of $\cdot \mathrm{OH}$ free radicals in the presence of $\mathrm{Ru} @ \mathrm{SiO}_{2}$, which can effectively destroy cancer cells. The storage stability of $\mathrm{Ru} @ \mathrm{SiO}_{2}-\mathrm{PA}$ suspended in aqueous and PBS solutions are illustrated in Fig. 2i. The size of the nanomaterials did not change significantly within 7 days, which suggests that the Ru@ $\mathrm{SiO}_{2}-\mathrm{PA}$ are stable enough for further investigation.

\section{$\mathrm{Ru} @ \mathrm{SiO}_{2}-\mathrm{PA}$ selectively inhibits cancer cells growth}

Increased evidences have confirmed that nano-Fenton reactors showed novel anticancer potential in tumor acidic microenvironment [16-18]. Herein, $\mathrm{Ru} @ \mathrm{SiO}_{2}-\mathrm{PA}-$ induced tumor microenvironment-response anticancer 
activity was firstly examined in different $\mathrm{pH}$ environment. As shown in Fig. 3a, $\mathrm{Ru} @ \mathrm{SiO}_{2}-\mathrm{PA}$ under pH 6.0 environment significantly inhibited cancer cells growth of HepG2, MCF-7 and SGC-7901 with a dose-dependent manner. $\mathrm{Ru} @ \mathrm{SiO}_{2}$ - $\mathrm{PA}$ under pH 7.4 environment only slightly inhibited cancer cells growth of HepG2, MCF-7 and SGC-7901. For instance, $\mathrm{Ru} @ \mathrm{SiO}_{2}$-PA (5, 10 and $20 \mu \mathrm{g} / \mathrm{ml}$ ) under $\mathrm{pH} 7.4$ environment only inhibited SGC7901 cells viability from $100 \%$ (control) to $80.1 \%, 75 \%$ and $68.2 \%$, respectively. However, $\mathrm{Ru} @ \mathrm{SiO}_{2}-\mathrm{PA}$ (5, 10 and $20 \mu \mathrm{g} / \mathrm{ml}$ ) under $\mathrm{pH} 6.0$ environment dose-dependently inhibited SGC-7901 cells viability from 100\% (control) to $51.2 \%, 37.2 \%$ and $17.5 \%$, respectively. $\mathrm{Ru} @ \mathrm{SiO}_{2}$ under pH 7.4 and pH 6.0 environment both caused slight cytotoxicity towards the three cancer cells lines. The $\mathrm{pH}-$ response anti-proliferation effect of $\mathrm{Ru} @ \mathrm{SiO}_{2}-\mathrm{PA}$ was further confirmed in human normal cells, and the result indicated that $\mathrm{Ru} @ \mathrm{SiO}_{2}-\mathrm{PA}$ under pH 6.0 environment showed better anti-proliferation effect against HUVECs than that of pH 7.0 environment. $\mathrm{Ru} @ \mathrm{SiO}_{2}$-PA-induced anticancer activity was further confirmed by Giemsa staining. As shown in Fig. 3b, $\mathrm{Ru} @ \mathrm{SiO}_{2}$-PA treatment dose-dependently inhibited SGC-7901 cells growth, as convinced by the decreased cells number. $\mathrm{Ru} @ \mathrm{SiO}_{2}$ treatment only caused slight change of SGC-7901 cells number. Taken together, our findings validated the rational design that ruthenium-loaded PA-modified mesoporous silica ( $\left.\mathrm{Ru} @ \mathrm{SiO}_{2}-\mathrm{PA}\right)$ can act as novel nano-Fenton reactors to achieve tumor microenvironment-response anticancer activity.

\section{Ru@SiO $-\mathrm{PA}$ induces enhanced cell apoptosis}

MTT results showed that $\mathrm{Ru} @ \mathrm{SiO}_{2}$-PA caused more cytotoxicity towards SGC-7901 cells, which herein were

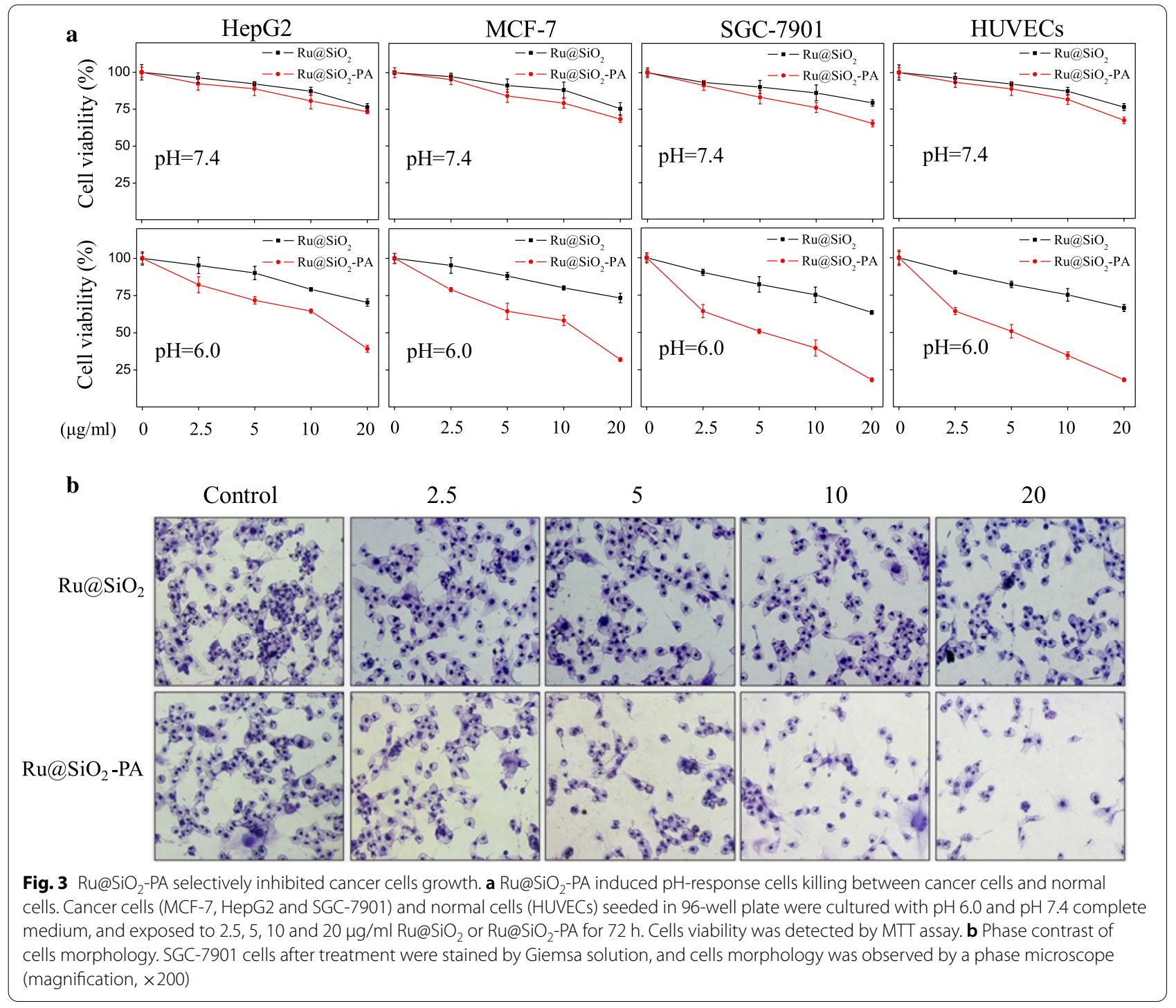


selected for further mechanism study. The extracellular ectropion of phosphatidylserine protein is usually considered as an index for cells early apoptosis [30]. Therefore, $\mathrm{Ru} @ \mathrm{SiO}_{2}$-PA-induced early apoptosis was primary detected by annexin V probe. As shown in Fig. 4a, Ru@ $\mathrm{SiO}_{2}$ treatment caused slight early apoptosis of SGC7901 cells, as convinced by the green fluorescence. However, $\mathrm{Ru} @ \mathrm{SiO}_{2}-\mathrm{PA}$ treatment dose-dependently triggered enhanced early apoptosis of SGC-7901 cells, as convinced by the enhanced green fluorescence. Caspase- 3 as the main apoptosis executor was also detected, and the result indicated that $\mathrm{Ru} @ \mathrm{SiO}_{2}-\mathrm{PA}$ treatment caused more activation of caspase-3 than that of $\mathrm{Ru} @ \mathrm{SiO}_{2}$ (Fig. 4b). Caspase-3 expression by western blot analysis further confirmed $\mathrm{Ru} @ \mathrm{SiO}_{2}$-PA-induced enhanced apoptosis of SGC-7901 cells (Fig. 4c). Moreover, $\mathrm{Ru@SiO} 2_{2}^{-}$ PA treatment also dose-dependently caused enhanced cytochrome-c release (Fig. 4c), which will irreversibly lead to apoptosis of SGC-7901 cells. Taken together, these results suggested that $\mathrm{Ru} @ \mathrm{SiO}_{2}-\mathrm{PA}$ after PA modification induced enhanced cancer cells apoptosis.

\section{Enhanced inhibitory effects on tumor spheroids}

To further confirm $\mathrm{Ru} @ \mathrm{SiO}_{2}$-PA-induced anticancer efficiency, 3D tumor spheroids of SGC-7901 cells were established in the present study, which was considered as a good tumor model in ex vivo. As shown in Fig. 5a, $\mathrm{Ru} @ \mathrm{SiO}_{2}$ treatment slightly inhibited the growth of SGC7901 tumor spheroids. However, $\mathrm{Ru} @ \mathrm{SiO}_{2}$-PA treatment dose-dependently induced enhanced growth inhibition against SGC-7901 tumor spheroids, as convinced by the decreased volume of tumor spheroids. The quantitative analysis of tumor spheroids volume further confirmed this inhibitory effect (Fig. 5b). For instance, $\mathrm{Ru} @ \mathrm{SiO}_{2}(5$, 10 and $20 \mu \mathrm{g} / \mathrm{ml}$ ) only inhibited the volume of SGC-7901 tumor spheroids from $100 \%$ (control) to $80.1 \%, 75 \%$ and $68.2 \%$, respectively. However, $\mathrm{Ru} @ \mathrm{SiO}_{2}-\mathrm{PA}(5,10$ and $20 \mu \mathrm{g} / \mathrm{ml}$ ) effectively inhibited the volume of SGC-7901 tumor spheroids from $100 \%$ (control) to $51.2 \%, 37.2 \%$ and $17.5 \%$, respectively. Taken together, these results demonstrated that $\mathrm{Ru} @ \mathrm{SiO}_{2}-\mathrm{PA}$ after PA modification induced enhanced growth inhibition against SGC-7901 tumor spheroids in ex vivo.
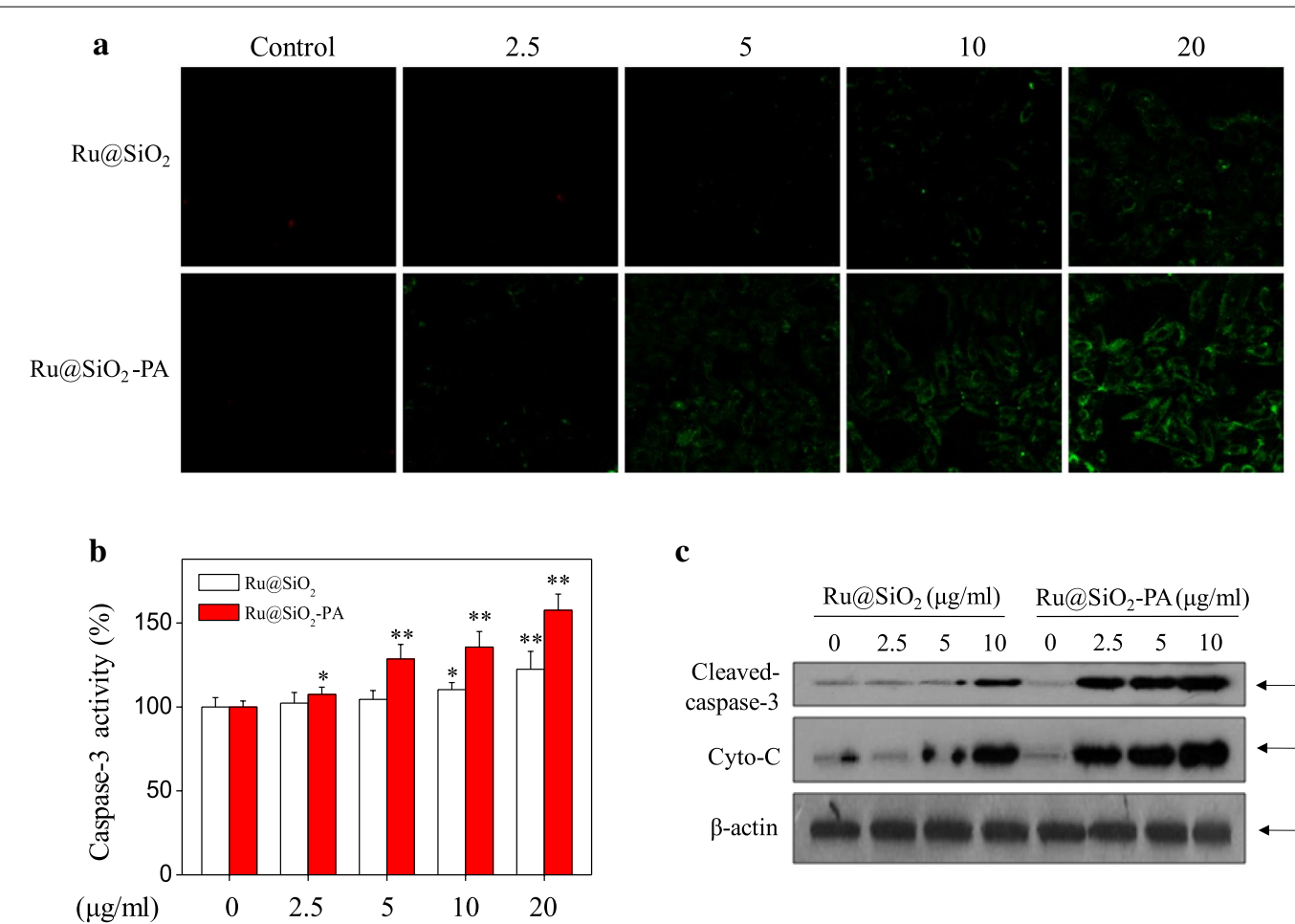

c

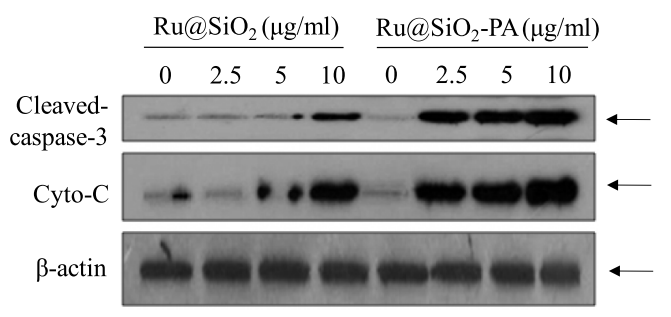

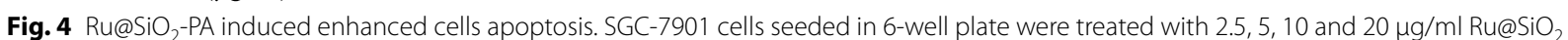
or Ru@SiO 2 -PA for $6 \mathrm{~h}$. Cells after treatment were loaded with AnnexinV probe and the early apoptosis was examined by fluorescent microscope (magnification, × 200). b Ru@SiO 2 -PA induced enhanced caspase-3 activation. SGC-7901 cells after treatment with Ru@SiO 2 or Ru@SiO 2 -PA for 72 h were collected and total protein was extracted. Caspase-3 activity was detected with a specific Ac-DEVD-AMC substrate by fluorescent microreader. c Ru@SiO $-\mathrm{PA}$ induced enhanced caspase-3 cleavage and cytochrome-c release. SGC-7901 cells after treatment with Ru@SiO ${ }_{2}$ or $\mathrm{Ru} @ S i O_{2}-\mathrm{PA}$ for $72 \mathrm{~h}$ were collected and total protein was extracted. Protein expression was detected by western bolt analysis. Bars with " ${ }^{\prime *}$ or ${ }^{\prime \prime * * *}$ represents $\mathrm{P}<0.05$ or $\mathrm{P}<0.01$ level, respectively 

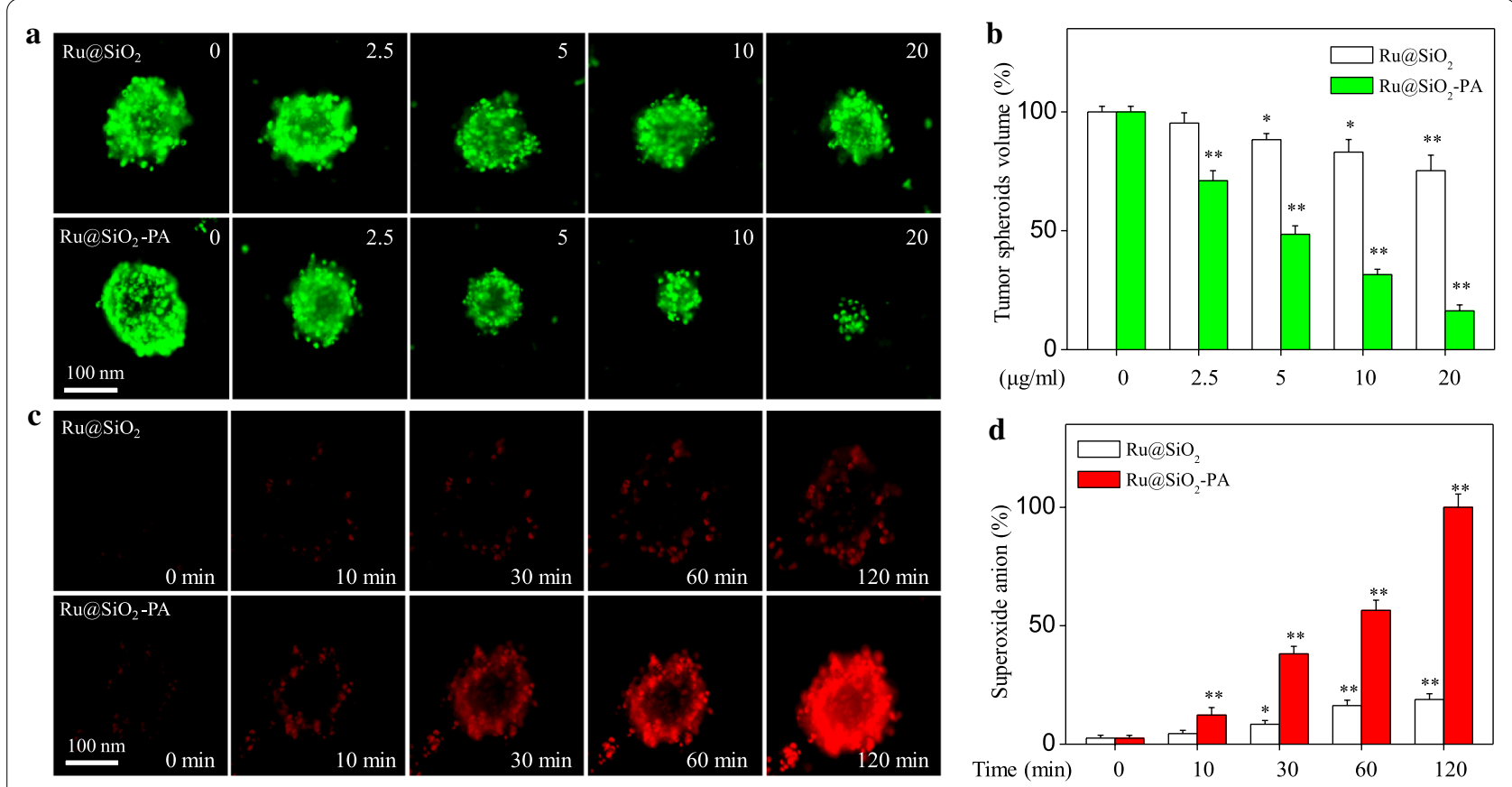

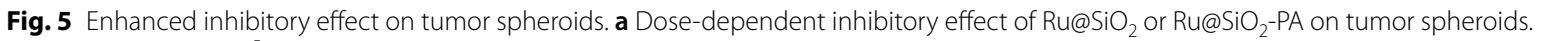
SGC-7901 cells $\left(6 \times 10^{5}\right.$ cells/well) were seeded in ultra-low attachment 6-well plate and cultured for 2 days. Then, tumor spheroids were treated with Ru@SiO or Ru@SiO $_{2}$-PA for 72 h, and imaged under a fluorescent microscope (magnification, 100 x). b Quantitative analysis of tumor spheroids volume. c Real-time images of superoxide anion. SGC-7901 tumor spheroids cultured for 5 days were pre-incubated with DHE probe and treated 20 mg/ml Ru@SiO 2 or Ru@SiO 2 -PA for 10-120 min. The Real-time generation of superoxide anion was imaged under a fluorescent microscope (magnification, $\times 100$ ). d Quantitative analysis of superoxide anion. Bars with "** or "***" represents $\mathrm{P}<0.05$ or $\mathrm{P}<0.01$ level, respectively

\section{$\mathrm{Ru} @ \mathrm{SiO}_{2}-\mathrm{PA}$ inhibits tumor xenografts growth in vivo}

To evaluate $\mathrm{Ru} @ \mathrm{SiO}_{2}$-PA-induced anticancer efficiency in vivo, nude mice bearing SGC-7901 tumor xenografts were employed in the present study. Nude mice were planted with SGC-7901 cells ( $10^{7}$ cells) by subcutaneous injection, and nude mice after 21-days growth showed notable tumors (Fig. 6a). Nude mice were administrated with 5 and $10 \mathrm{mg} / \mathrm{kg} \mathrm{Ru@SiO}{ }_{2}-\mathrm{PA}$ for 21 days by tail intravenous injection every other day, and the results showed that $\mathrm{Ru} @ \mathrm{SiO}_{2}-\mathrm{PA}$ administration effectively inhibited SGC-7901 tumor xenografts in vivo, as convinced by the decreased tumor volume (Fig. 6b). The real-time change curve of tumor volume (Fig. 6c) further confirmed $\mathrm{Ru} @ \mathrm{SiO}_{2}$-PA-induced anticancer efficiency in vivo. $\mathrm{Ru} @ \mathrm{SiO}_{2}-\mathrm{PA}$ administration in vivo caused no significant change of mice body weight (Fig. 6d). The anticancer mechanism of Ru@ $\mathrm{SiO}_{2}$-PA in vivo was also explored. As shown in Fig. 6e, $\mathrm{Ru} @ \mathrm{SiO}_{2}-\mathrm{PA}$ administration significantly caused caspase-3 activation, indicating that $\mathrm{Ru} @ \mathrm{SiO}_{2}-\mathrm{PA}$ induced tumor cells apoptosis in vivo. Taken together, these results demonstrated that $\mathrm{Ru} @ \mathrm{SiO}_{2}-\mathrm{PA}$ had the potential to inhibit tumor xenografts growth in vivo by induction of apoptosis.

\section{Biodistribution of $\mathrm{Ru} @ \mathrm{SiO}_{2}-\mathrm{PA}$ in vitro and in vivo}

Studies have verified that ruthenium can induce DNAtargeted incorporation and emit bright red fluorescence, which can be used to monitor the real-time biodistribution of $\mathrm{Ru} @ \mathrm{SiO}_{2}-\mathrm{PA}$ in vitro and in vivo. As shown in Fig. 7a, SGC-7901 cells exposed to $2.5 \mu \mathrm{g} /$ $\mathrm{ml} \mathrm{Ru} @ \mathrm{SiO}_{2}$-PA showed time-dependent red fluorescence. The real-time imaging of $\mathrm{Ru} @ \mathrm{SiO}_{2}-\mathrm{PA}$ in SGC7901 cells vividly convinced that the biodistribution of $\mathrm{Ru} @ \mathrm{SiO}_{2}-\mathrm{PA}$ in vitro was mainly at nucleus. What's more, the biodistribution of $\mathrm{Ru} @ \mathrm{SiO}_{2}-\mathrm{PA}$ in vivo was also monitored in nude mice by fluorescence imaging system. As shown in Fig. 7b, nude mice after tail intravenous injection of $10 \mathrm{mg} / \mathrm{kg} \mathrm{Ru} @ \mathrm{SiO}_{2}-\mathrm{PA}$ showed obvious fluorescence with a time-dependent manner. The real-time imaging of $\mathrm{Ru} @ \mathrm{SiO}_{2}-\mathrm{PA}$ in nude mice vividly convinced that the biodistribution of $\mathrm{Ru} @ \mathrm{SiO}_{2}-$ PA in vivo was mainly at SGC-7901 tumor xenografts. Taken together, these results validated that ruthenium loading endowed $\mathrm{Ru} @ \mathrm{SiO}_{2}-\mathrm{PA}$ with real-time monitoring property. 


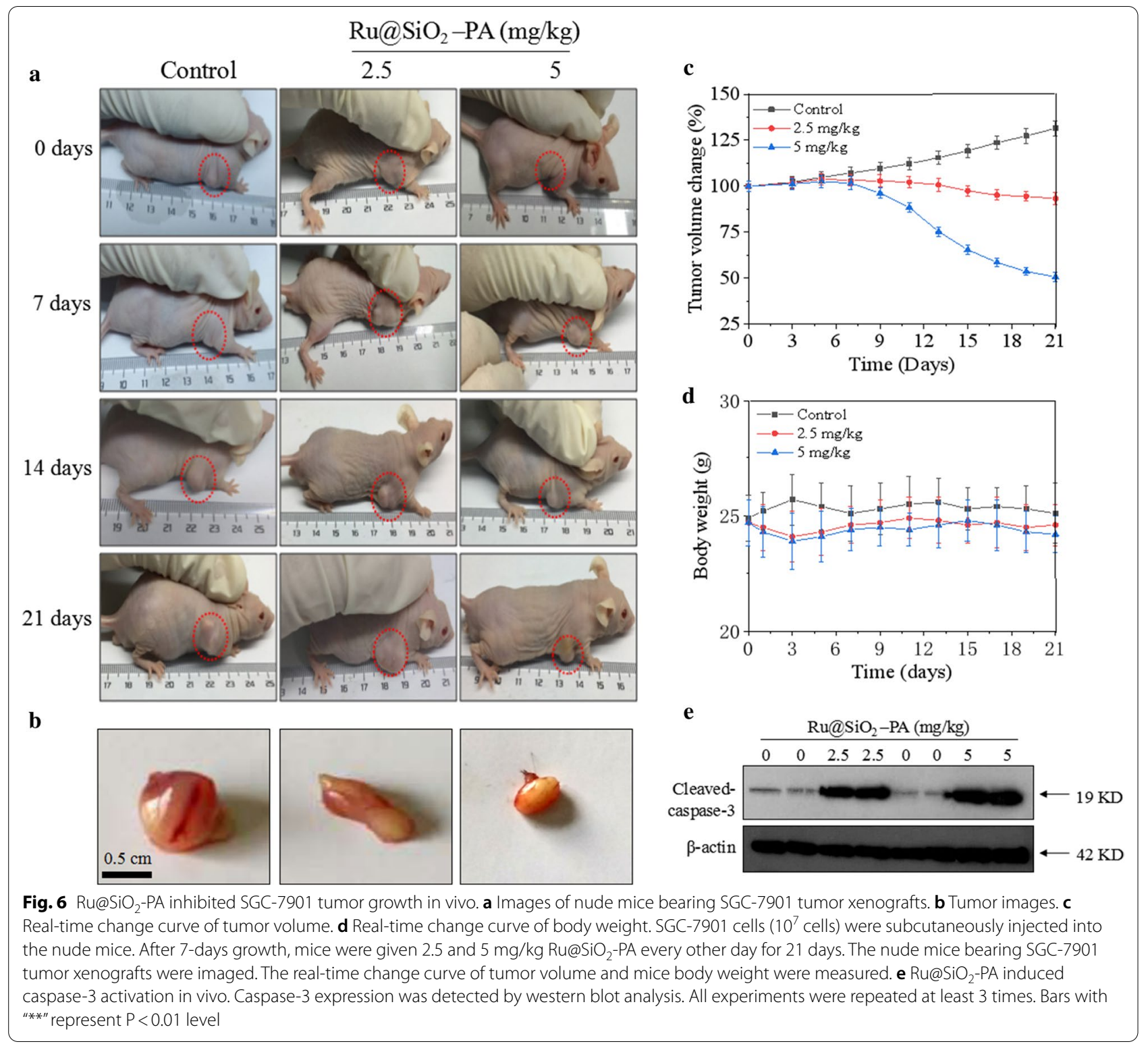

\section{$\mathrm{Ru} @ \mathrm{SiO}_{2}-\mathrm{PA}$ causes enhanced dysfunction of MAPKs and PI3K/AKT pathways}

MAPKs (including p38, JNK and ERK) and PI3K/AKT pathways are the two most important pathways in regulating cells proliferation, cell growth and cell apoptosis [31-33]. ROS-mediated oxidative stress as an early apoptotic event was located at the upstream of MAPKs and PI3K/AKT pathways. Studies have verified that dysfunction of MAPKs and PI3K/AKT pathways both contributed to nano-drugs-induced anticancer mechanisms [34-36]. Hence, the status of MAPKs and PI3K/ AKT pathways in $\mathrm{Ru@SiO}$-PA-treated SGC-7901 cells was evaluated by western blot analysis. As shown in Fig. 8a, b, $\mathrm{Ru} @ \mathrm{SiO}_{2}$ treatment slightly activated MAPKs and inactivated PI3K/AKT pathway in SGC-7901 cells. However, $\mathrm{Ru} @ \mathrm{SiO}_{2}$-PA treatment dose-dependently induced enhanced activation of MAPKs and inactivation of PI3K/AKT pathway, as convinced by the enhanced phosphorylation level of JNK, p38 and ERK, and decreased phosphorylation level of AKT, respectively (Fig. 8a, b). To further confirm the significance of MAPKs and PI3K/AKT pathways, four inhibitors of the two pathways were employed. The results indicated that ERK inhibitor by U0126 significantly attenuated Ru@ $\mathrm{SiO}_{2}$-PA-induced ERK activation (Fig. 8c). Meanwhile, AKT inhibitor by LY294002 significantly enhanced $\mathrm{Ru} @ \mathrm{SiO}_{2}$-PA-induced AKT inactivation (Fig. 8d). 

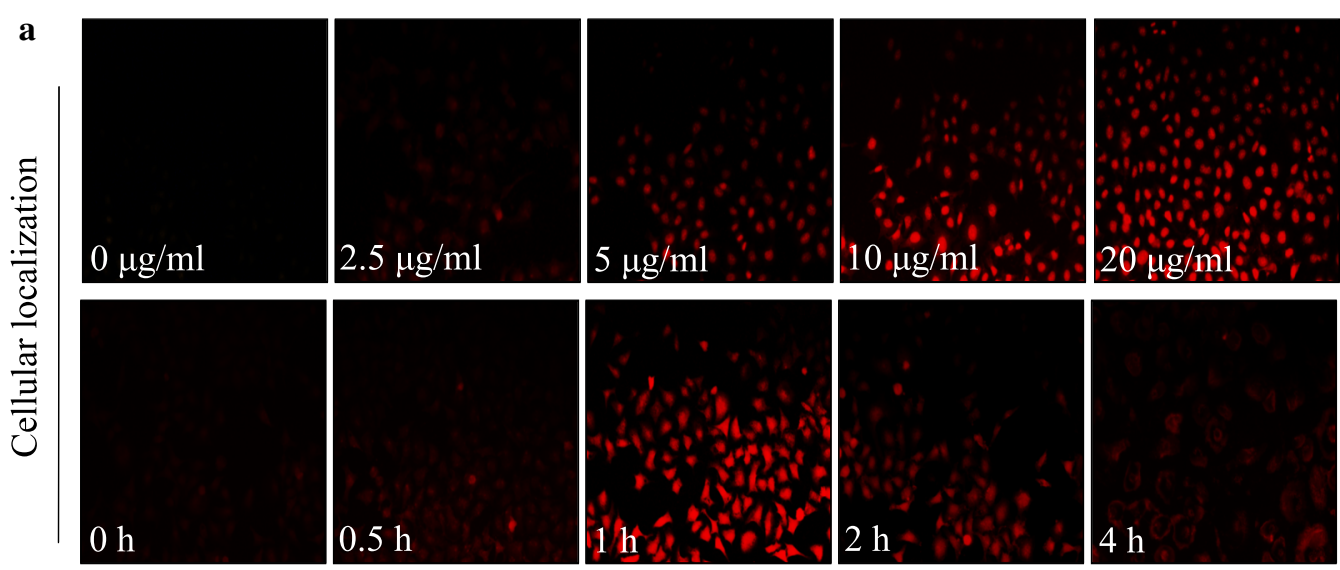

b

$\mathrm{Ru} @ \mathrm{SiO}_{2}-\mathrm{PA}(10 \mathrm{mg} / \mathrm{kg})$

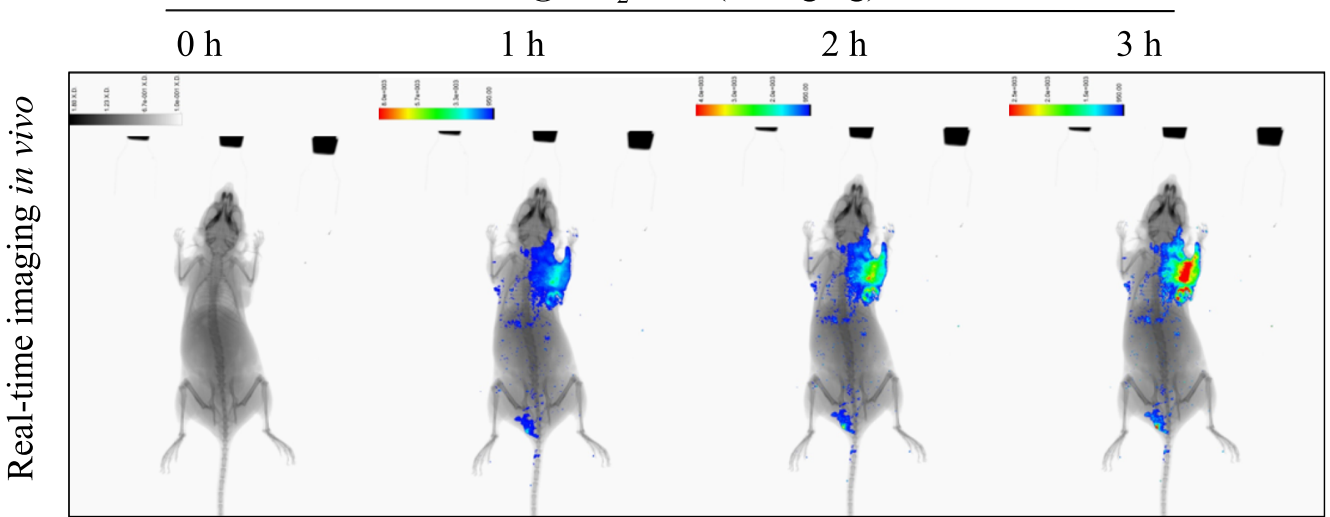

Fig. 7 Biodistribution of Ru@SiO 2 -PA in vitro and in vivo. a Dose-dependent and time-dependent imaging in vitro. SGC-7901 cells were treated with 0-20 $\mu \mathrm{g} / \mathrm{ml} \mathrm{Ru@SiO} 2-\mathrm{PA}$ for $4 \mathrm{~h}$, or cells were treated with $10 \mu \mathrm{g} / \mathrm{ml}$ Ru@SiO $2-\mathrm{PA}$ for 0-4 h. The biodistribution of Ru@SiO - -PA in vitro were

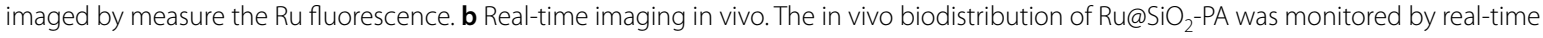
imaging in nude mice. Ru@SiO ${ }_{2}-\mathrm{PA}(10 \mathrm{mg} / \mathrm{kg}$ ) was given by tail vein injection, and real-time imaging of Ru fluorescence at 1,2 and $3 \mathrm{~h}$ was detected by in vivo fluorescence imaging system (Caliper Perkin Elmer)

Effects of four inhibitors on cells viability further confirmed this conclusion (Fig. 8e). As shown in Fig. 8e, pre-treatment of SGC-7901 cells with LY294002 (AKT inhibitor) significantly enhanced $\mathrm{Ru} @ \mathrm{SiO}_{2}$-PA-induced growth inhibition against SGC-7901 cells. Pre-treatment of SGC-7901 cells with U0126 (ERK inhibitor) or SB202190 (p38 inhibitor) both significantly attenuated $\mathrm{Ru} @ \mathrm{SiO}_{2}$-PA-induced growth inhibition against SGC-7901 cells (Fig. 8e). Pre-treatment of SGC-7901 cells with SP600125 (JNK inhibitor) caused no significant change of $\mathrm{Ru} @ \mathrm{SiO}_{2}$-PA-induced cell growth. Taken together, these results suggested that $\mathrm{Ru} @ \mathrm{SiO}_{2}-$ PA inhibited anticancer cells growth with MAPKs- and PI3K/AKT-dependent manner, which validated that $\mathrm{Ru} @ \mathrm{SiO}_{2}$-PA after PA modification caused enhanced dysfunction of MAPKs and PI3K/AKT pathways.
$\mathrm{Ru} @ \mathrm{SiO}_{2}-\mathrm{PA}$ triggers enhanced oxidative damage in vitro and ex vivo

$\mathrm{H}_{2} \mathrm{O}_{2}$ in acid tumor microenvironment was generated by Fenton reaction in the presence of $\mathrm{PA}$, and $\mathrm{H}_{2} \mathrm{O}_{2}$ can be reduced by $\mathrm{Ru}^{2+}$ into $\cdot \mathrm{OH}$, which will cause oxida-

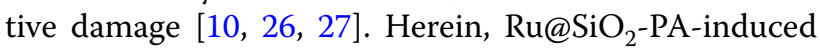
oxidative damage was examined in vitro and $e x$ in vivo. As shown in Fig. 9a, $\mathrm{Ru} @ \mathrm{SiO}_{2}$ treatment slightly induced the generation of superoxide anion. However, ${\mathrm{Ru} @ \mathrm{SiO}_{2}-}^{-}$ PA treatment time-dependently induced enhanced generation of superoxide anion in vitro, as convinced by the enhanced red fluorescence. The quantitative analysis of superoxide anion accumulation further confirmed this effect (Fig. 9b). The enhanced generation of superoxide anion was also detected in tumor spheroids ex vivo (Fig. 5c, d). Overproduction of superoxide anion will trigger DNA damage. As shown in Fig. 9c, $\mathrm{Ru@SiO}$ treatment slightly triggered DNA damage. However, Ru@ 
$\mathbf{a}$

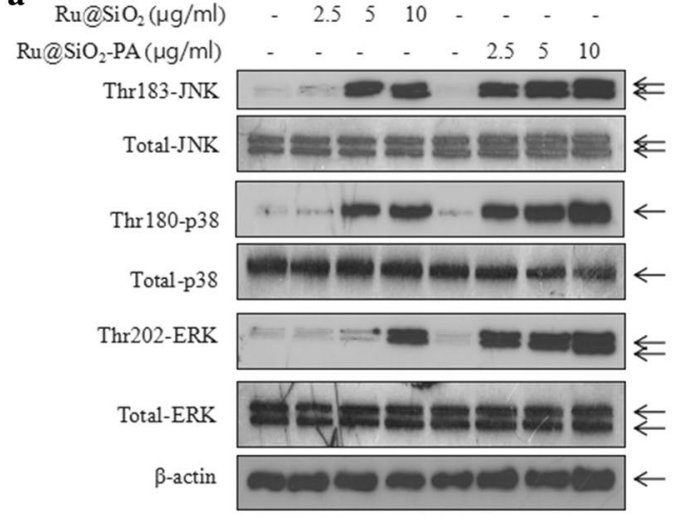

c

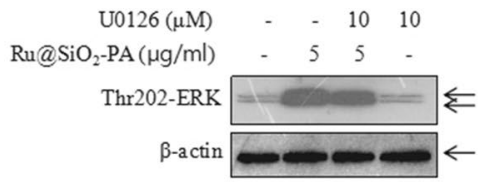

d

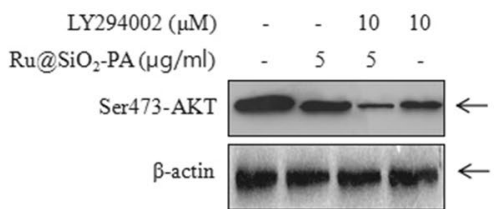

b

$\mathrm{Ru} @ \mathrm{SiO}_{2}(\mu \mathrm{g} / \mathrm{ml}) \quad-\quad \begin{array}{llllllllll} & 2.5 & 5 & 10 & - & - & -\end{array}$

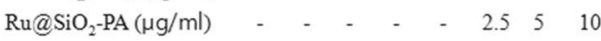

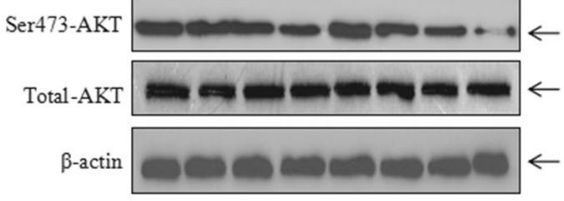

e

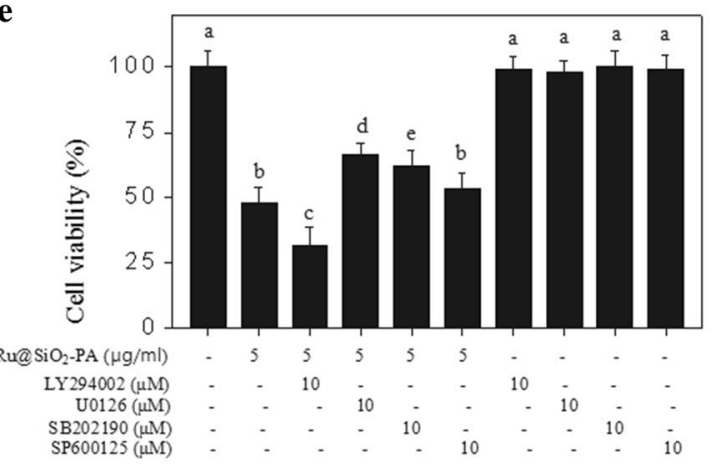

Fig. 8 Enhanced dysfunction of MAPKs and PI3K/AKT pathways. a Dose-dependent dysfunction of MAPKs pathway. b Dose-dependent dysfunction of PI3K/AKT pathway. c Effect of U0126 (ERK inhibitor) on p-ERK expression in Ru@SiO 2 -PA-treated cells. d Effect of LY294002 (AKT inhibitor) on p-AKT expression in Ru@SiO 2 -PA-treated cells. e Effects of four inhibitors on Ru@SiO 2 -PA-treated cells viability. SGC-7901 cells were pre-treated with inhibitors for $2 \mathrm{~h}$ or/and co-treated with $2.5-10 \mu \mathrm{g} / \mathrm{ml}$ Ru@SiO 2 or Ru@SiO ${ }_{2}-\mathrm{PA}$ for 72 h. Protein expression was examined by western blot analysis. Cells viability was detected by MTT assay. Bars with different letters indicate the $\mathrm{P}<0.05$ level

$\mathrm{SiO}_{2}$-PA treatment dose-dependently triggered enhanced DNA damage, as convinced by the enhanced phosphorylation level of ATM, ATR, p53 and histone. Taken together, these results validated the rational design that ruthenium-loaded PA-modified mesoporous silica (Ru@ $\left.\mathrm{SiO}_{2}-\mathrm{PA}\right)$ can act as novel nano-Fenton reactors to trigger tumor microenvironment-response oxidative damage in cancer cells (Fig. 10).

\section{Safety evaluation}

Drugs safety was an important index for anticancer drugs design. Herein, side effects of $\mathrm{Ru} @ \mathrm{SiO}_{2}-\mathrm{PA}$ were examined in vitro and in vivo. As shown in Fig. 3a, $\mathrm{Ru} @ \mathrm{SiO}_{2}-$ PA under $\mathrm{pH} 6.0$ and $\mathrm{pH} 7.4$ showed distinct cells killing. That is, $\mathrm{Ru} @ \mathrm{SiO}_{2}-\mathrm{PA}$ showed less toxicity towards human normal cells in vitro, which validated that $\mathrm{Ru} @ \mathrm{SiO}_{2}-\mathrm{PA}$ as novel nano-Fenton reactors displayed super selectivity between cancer cells and normal cells. The in vivo side effects of $\mathrm{Ru} @ \mathrm{SiO}_{2}-\mathrm{PA}$ in mice were also examined. Nude mice after administration with 5 and $10 \mathrm{mg} / \mathrm{kg} \mathrm{Ru@SiO} 2_{2}^{-}$ PA for 21 days was given euthanasia, and main organs were collected, cut into $4 \mu \mathrm{M}$ slices and stained by $\mathrm{H} \& \mathrm{E}$ for histopathological examination. As shown in Fig. 11a, $\mathrm{Ru} @ \mathrm{SiO}_{2}-\mathrm{PA}$ administration in vivo caused no obvious impairment and inflammation of heart, liver, spleen, lung, kidney and brain compared to that of the control groups. Moreover, blood biochemical indexes were also assayed by ELISA methods. As shown in Fig. 11b-g, nude mice after $\mathrm{Ru} @ \mathrm{SiO}_{2}-\mathrm{PA}$ administration showed no significant changes of blood glucose (GLU), cholesterol (CHOL), serum creatinine (CREA), albumen (ALB), globulin (GLB) and lactate dehydrogenase (LDH), indicating the health of kidney, liver and heart. Taken together, these results indicated the safety of $\mathrm{Ru} @ \mathrm{SiO}_{2}-\mathrm{PA}$ in vitro and in vivo with potential application in clinic.

\section{Conclusion}

In the present study, ruthenium-loaded palmitoyl ascorbate (PA)-modified mesoporous silica (Ru@ $\left.\mathrm{SiO}_{2}-\mathrm{PA}\right)$ was successfully fabricated and characterized, and the results indicated that $\mathrm{Ru} @ \mathrm{SiO}_{2}-\mathrm{PA}$ under pH6.0 environment displayed enhanced growth 


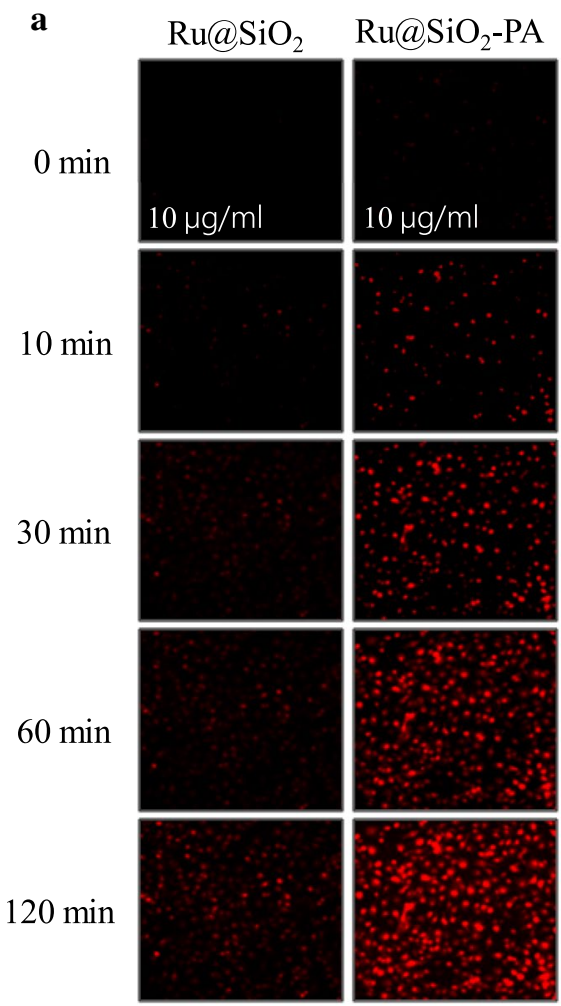

b
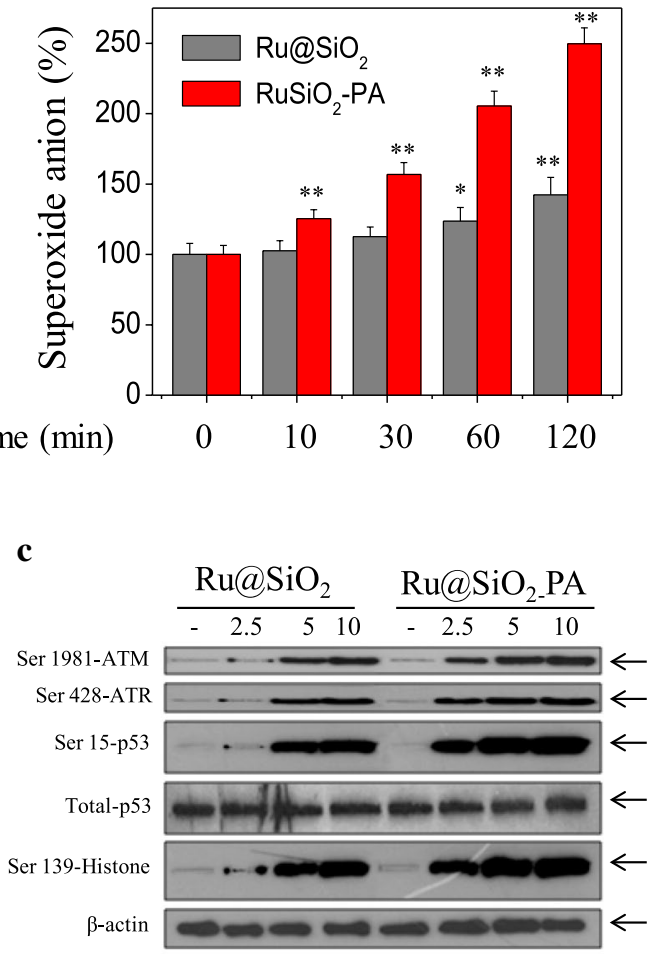

Fig. 9 Ru@SiO 2 -PA triggers enhanced oxidative damage. a Real-time imaging of superoxide anion. SGC-7901 cells were pre-loaded with $10 \mu \mathrm{M}$ DHE probe for 15 min in darkness, and treated with $10 \mu \mathrm{g} / \mathrm{ml}$ Ru@SiO ${ }_{2}$ or $\mathrm{Ru}_{\mathrm{SiO}}-\mathrm{PA}$ for 10-120 min. The real-time generation of superoxide anion was imaged under a fluorescent microscope (magnification, $\times 100$ ). $\mathbf{b}$ Quantitative analysis of superoxide anion. Generation of superoxide anion was quantified as \% of the control. c Ru@SiO ${ }_{2}-\mathrm{PA}$ triggered enhanced DNA damage. Several DNA damaging markers were examined by western blot analysis. Bars with "** or "**" represents $\mathrm{P}<0.05$ or $\mathrm{P}<0.01$ level, respectively

a $\mathrm{Ru} @ \mathrm{SiO}_{2}-\mathrm{PA}(\mu \mathrm{g} / \mathrm{ml}) \quad-\quad 5 \quad 5 \quad-$

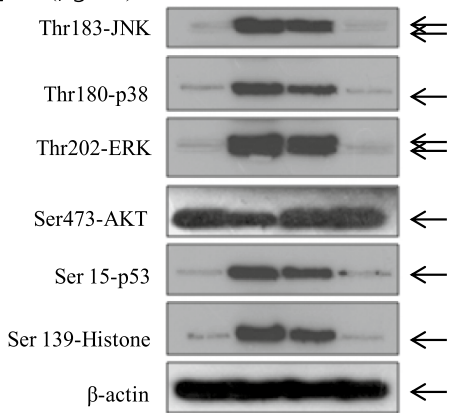

b

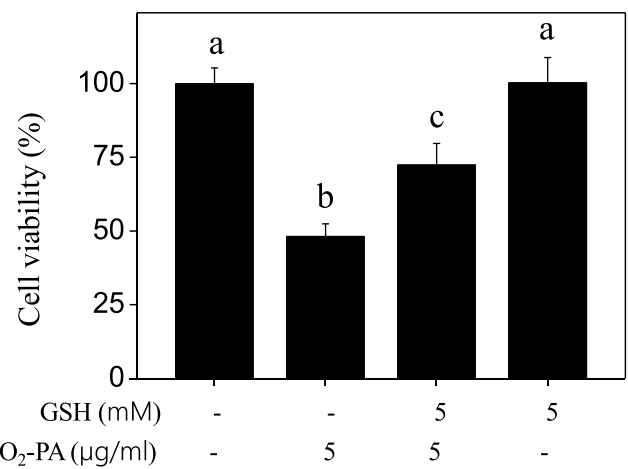

Fig. 10 Inhibition of ROS decreased Ru@SiO 2 -PA-induced anticancer activity. a Inhibition of ROS by glutathione (GSH) inhibited Ru@ $\mathrm{SiO}_{2}$-PA-induced dysfunction of MAPKs and PI3K/AKT pathways and DNA damage. b Inhibition of ROS inhibited Ru@SiO ${ }_{2}$-PA-induced anticancer activity. SGC-7901 cells were pre-treated with $5 \mathrm{mM} \mathrm{GSH}$ for $2 \mathrm{~h}$ and co-treated with $5 \mu \mathrm{g} / \mathrm{ml}$ Ru@SiO 2 -PA for 72 h. Protein expression was examined by western blot analysis. Cells viability was assayed by MTT assay. Bars with different letters indicate the $\mathrm{P}<0.05$ level

inhibition and apoptosis against human cancer cells in vitro and in vivo. Mechanism investigation revealed that $\mathrm{Ru} @ \mathrm{SiO}_{2}-\mathrm{PA}$ triggered ROS-mediated DNA damage and dysfunction of MAPKs and PI3K/AKT pathways. Importantly, $\mathrm{Ru} @ \mathrm{SiO}_{2}-\mathrm{PA}$ showed no side 


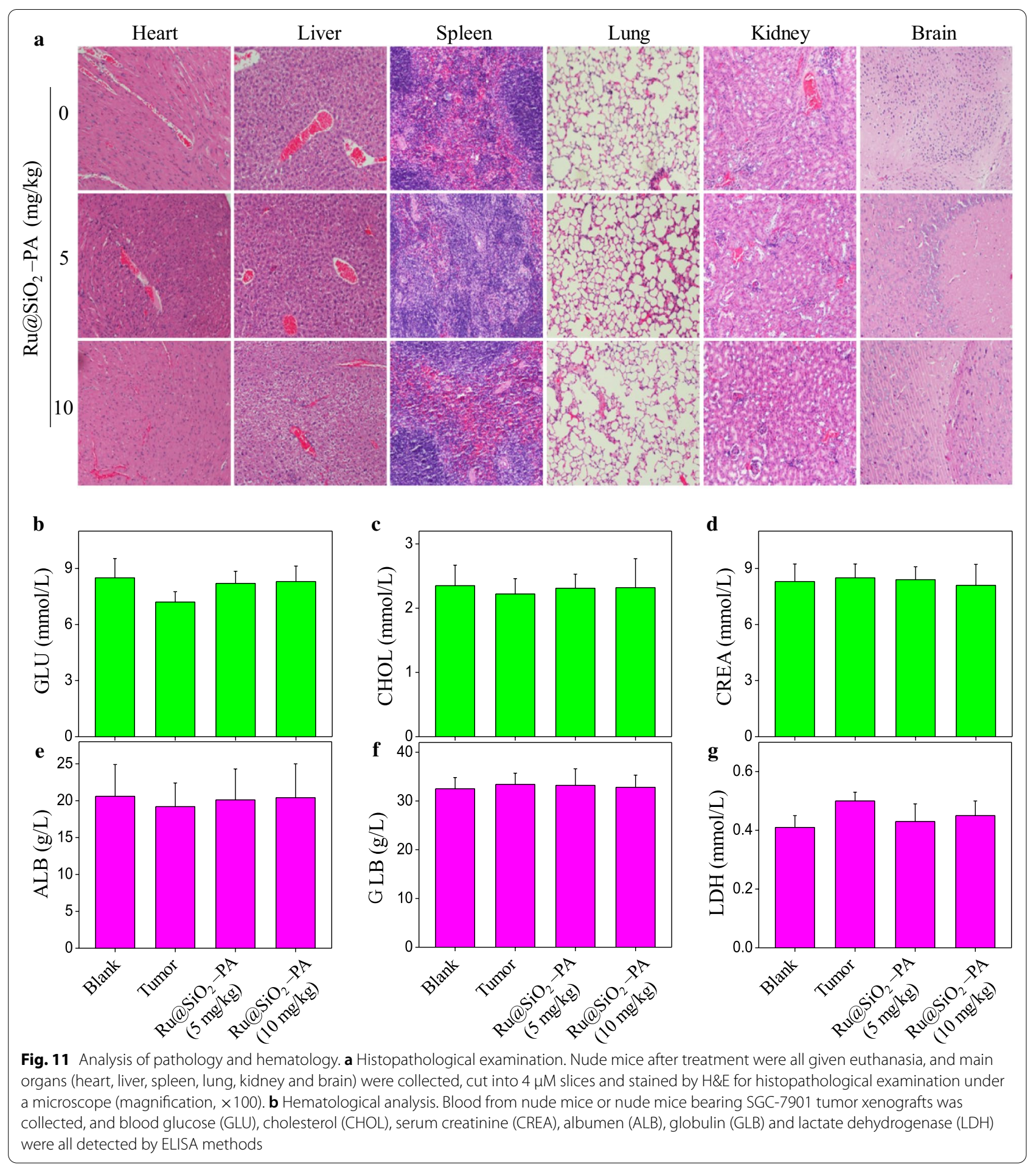

effects in vivo, which validated the rational design that ruthenium-loaded PA-modified mesoporous silica $\left(\mathrm{Ru} @ \mathrm{SiO}_{2}-\mathrm{PA}\right)$ can act as novel tumor 
microenvironment-response nano-Fenton reactors for cancer precise therapy.

\section{Acknowledgments}

Thanks for the technical support provided by the Biotechnology Center of the State Key Laboratory of Anhui Agricultural University for this research.

\section{Authors' contributions}

CDF, DDS and B.L. Sun contributed to this experiment design. ZKW, PZ, CYY, JYW, YS and YC performed the experiments. ZKW, CDF, DDS and WYW wrote this manuscript. All authors contributed to the data analysis and revised the manuscript. All authors read and approved the final manuscript.

\section{Funding}

This work was supported by a Major Science and Technology Project of Anhui Province (17030701023), the National Natural Science Foundation of China (21401002, 81501106), the Scientific Research Project of Anhui Education Department (KJ2019A0182), Key projects of youth talent fund in Anhui Provincial Universities (gxyqZD2020006), Natural Science Foundation of Shandong Province (ZR2020MH134), and Shandong Introduction and Education Program of Young Innovative Talents (RCJF007).

\section{Availability of data and materials}

The datasets used and/or analyzed during the current study are available within the manuscript

\section{Declarations}

\section{Ethics approval and consent to participate}

The study was reviewed and approved by the Ethics Committee of Anhui Agricultural University.

\section{Consent for publication}

All authors of this study agreed to publish.

\section{Competing interests}

The authors have declared that no competing interest exists.

\section{Author details}

1 School of Life Sciences, Anhui Agricultural University, Hefei 230036, China.

${ }^{2}$ Department of Cardiovascular Medicine, Taian City Central Hospital, Taian 271000, Shandong, China. ${ }^{3}$ Department of Neurology, Second Affiliated Hospital; Key Lab of Cerebral Microcirculation in Universities of Shandong, Shandong First Medical University \& Shandong Academy of Medical Sciences, Taian 271000, Shandong, China.

Received: 13 January 2021 Accepted: 31 March 2021

Published online: 07 April 2021

\section{References}

1. Trachootham D, Lu WQ, Ogasawara MA, Valle NRD, Huang P. Redox regulation of cell survival. Antioxid Redox Sign. 2008;10:1343.

2. Schumacker PT. Reactive oxygen species in cancer cells: Live by the sword, die by the sword. Cancer Cell. 2006;10:175.

3. Schumacker PT. Reactive oxygen species in cancer: a dance with the devil. Cancer Cell. 2015:27:156.

4. Cao Z, Zhang L, Liang K, Cheong S, Boyer C, Gooding JJ, Chen Y, Gu Z. Biodegradable 2D fe-al hydroxide for nanocatalytic tumor-dynamic therapy with tumor specificity. Adv Sci. 2018;5:1801155

5. Lippert AR, De Bittner GCV, Chang CJ. Boronate oxidation as a bioorthogonal reaction approach for studying the chemistry of hydrogen peroxide in living systems. Accounts Chem Res. 2011;44:793.

6. Ozben T. Oxidative stress and apoptosis: impact on cancer therapy. J Pharm Sci. 2007:96:2181.

7. Fang J, Seki T, Maeda H. Therapeutic strategies by modulating oxygen stress in cancer and inflammation. Adv Drug Delivery Rev. 2009;61:290.
8. Engel RH, Evens AM. Oxidative stress and apoptosis: a new treatment paradigm in cancer. Front Biosci. 2006;11:300.

9. Fruehauf JP, Meyskens FL. Reactive oxygen species: A breath of life or death? Clin Cancer Res. 2007;13:789.

10. Cao ZB, Li B, Sun LY, Li L, Xu ZP, Gu Z. 2D layered double hydroxide nanoparticles: recent progress toward preclinical/clinical nanomedicine. Small Methods. 2020:4:20

11. Hanahan D, Weinberg RA. Hallmarks of Cancer: The Next Generation. Cell. 2011;144:646.

12. Trachootham D, Alexandre J, Huang P. Targeting cancer cells by ROSmediated mechanisms: a radical therapeutic approach? Nat Rev Drug Discov. 2009:8:579.

13. Woo SH, Park IC, Park MJ, Lee HC, Lee SWJ, Chun YJ, Lee SH, Hong SI, Rhee $\mathrm{CH}$. Arsenic trioxide induces apoptosis through a reactive oxygen species-dependent pathway and loss of mitochondrial membrane potential in HeLa cells. Int J Oncol. 2002;21:57.

14. Sawa T, Wu J, Akaike T, Maeda H. Tumor-targeting chemotherapy by a xanthine oxidase-polymer conjugate that generates oxygen-free radicals in tumor tissue. Cancer Res. 2000;60:666.

15. Fan WP, Lu N, Huang P, Liu Y, Yang Z, Wang S, Yu GC, Liu YJ, Hu JK, He QJ, et al. Glucose-responsive sequential generation of hydrogen peroxide and nitric oxide for synergistic cancer starving-like/gas therapy. Angew Chem-Int Edit. 2017:56:1229.

16. Qian XQ, Zhang J, Gu Z, Chen Y. Nanocatalysts-augmented fenton chemical reaction for nanocatalytic tumor therapy. Biomaterials. 2019;211:1.

17. Zhang C, Bu WB, Ni DL, Zhang SJ, Li Q, Yao ZW, Zhang JW, Yao HL, Wang Z, Shi JL. Synthesis of iron nanometallic glasses and their application in cancer therapy by a localized fenton reaction. Angew Chem-Int Edit. 2016:55:2101

18. Kwon B, Han E, Cho W, Yoo W, Hwang J, Kwon BM, Lee D. Nano-fenton reactors as a new class of oxidative stress amplifying anticancer therapeutic agents. Acs Appl Mate Inter. 2016;8:5887.

19. Hsu PP, Sabatini DM. Cancer cell metabolism: Warburg and beyond. Cell. 2008;134:703.

20. Mura S, Nicolas J, Couvreur P. Stimuli-responsive nanocarriers for drug delivery. Nat Mater. 2013:12:991.

21. Zhang SP, Zheng HL, Chen YJ, Yi H, Dai H, Hong ZS, Lin YY. Electrochemiluminescence Resonance Energy Transfer between Ru(bpy)(3)(2+) and CdZnSe@ZnSe Quantum Dots for Ovarian Cancer Biomarker Detection. Acs Appl Nano Mater. 2019:2:7061.

22. Chen Q, Espey MG, Sun AY, Lee JH, Krishna MC, Shacter E, Choyke PL, Pooput C, Kirk KL, Buettner GR, et al. Ascorbate in pharmacologic concentrations selectively generates ascorbate radical and hydrogen peroxide in extracellular fluid in vivo. Proc Nati Acad Sci USA. 2007:104:8749.

23. Sawant RR, Vaze OS, D'Souza GGM, Rockwell K, Torchilin VP. Palmitoyl ascorbate-loaded polymeric micelles: cancer cell targeting and cytotoxicity. Pharm Res. 2011;28:301.

24. Chen Q, Espey MG, Sun AY, Pooput C, Kirk KL, Krishna MC, Khosh DS, Drisko J, Levine M. Pharmacologic doses of ascorbate act as a prooxidant and decrease growth of aggressive tumor xenografts in mice. P Nati Acad Sci USA. 2008;105:11105.

25. Sawant RR, Vaze OS, Wang T, D'Souza GGM, Rockwell K, Gada K, Khaw BA, Torchilin VP. Palmitoyl ascorbate liposomes and free ascorbic acid: comparison of anticancer therapeutic effects upon parenteral administration. Pharm Res. 2012:29:375.

26. Huang G, Chen HB, Dong Y, Luo XQ, Yu HJ, Moore Z, Bey EA, Boothman DA, Gao JM. Superparamagnetic iron oxide nanoparticles: amplifying ROS stress to improve anticancer drug efficacy. Theranostics. 2013;3:116.

27. Bystrom LM, Guzman ML, Rivella S. Iron and reactive oxygen species: friends or foes of cancer cells? Antioxid Redox Sign. 2014:20:1917.

28. Ma PA, Xiao HH, Yu C, Liu JH, Cheng ZY, Song HQ, Zhang XY, Li CX, Wang JQ, Gu Z, et al. Enhanced cisplatin chemotherapy by iron oxide nanocarrier-mediated generation of highly toxic reactive oxygen species. Nano Lett. 2017:17:928.

29. Yin W, Li JJ, Ke WD, Zha ZS, Ge ZS. Integrated nanoparticles to synergistically elevate tumor oxidative stress and suppress antioxidative capability for amplified oxidation therapy. Acs Appl Mater Inte. 2017;9:29538.

30. Huang J, Huang W, Zhang ZH, Ling XR, Lin H, Peng LJ, Chen TF. Highly uniform synthesis of selenium nanoparticles with EGFR targeting and tumor microenvironment-responsive ability for simultaneous diagnosis 
and therapy of nasopharyngeal carcinoma. Acs Appl Mater Inter. 2019:11:11177.

31. Zhu LZ, Hou YJ, Zhao M, Yang ML, Fu XT, Sun JY, Fu XY, Shao LR, Zhang HF, Fan $C D$, et al. Caudatin induces caspase-dependent apoptosis in human glioma cells with involvement of mitochondrial dysfunction and reactive oxygen species generation. Cell Biol Toxicol. 2016;32:333.

32. Zhao SJ, Wang XJ, Wu QJ, Liu D, Li DW, Fu XT, Zhang HF, Shao LR, Sun JY, Sun BL, et al. Induction of G1 cell cycle arrest in human glioma cells by salinomycin through triggering ROS-Mediated DNA damage in vitro and in vivo. Neurochem Res. 2017;42:997.

33. Wang K, Fu XY, Fu XT, Hou YJ, Fang J, Zhang S, Yang MF, Li DW, Mao LL, Sun JY, et al. DSePA antagonizes high glucose-induced neurotoxicity: evidences for DNA damage-mediated p53 phosphorylation and MAPKs and AKT pathways. Mol Neurobiol. 2016;53:4363.

34. Zhang WW, Ding XY, Cheng H, Yin CY, Yan J, Mou ZP, Wang WY, Cui DX, Fan CD, Sun DD. Dual-targeted gold nanoprism for recognition of early apoptosis, dual-model imaging and precise cancer photothermal therapy. Theranostics. 2019;9:5610.

35. Wang ZK, Zhang P, Ding XY, Wang JY, Sun Y, Yin CY, Wang WY, Fan CD, Sun DD. Co-delivery of ampicillin and $\beta$-lactamase inhibitor by selenium nanocomposite to achieve synergistic anti-infective efficiency through overcoming multidrug resistance. Chem Eng J. 2021. https://doi.org/10. 1016/j.cej.2021.128908

36. Sun Y, Wang ZK, Zhang P, Wang JY, Chen Y, Yin CY, Wang WY, Fan CD, Sun DD. Mesoporous silica integrated with $\mathrm{FE}_{3} \mathrm{O}_{4}$ and palmitoyl ascorbate as a new nano-fenton reactor for amplified tumor oxidation therapy. Biomater Sci. 2020;8:7154.

\section{Publisher's Note}

Springer Nature remains neutral with regard to jurisdictional claims in published maps and institutional affiliations.
Ready to submit your research? Choose BMC and benefit from:

- fast, convenient online submission

- thorough peer review by experienced researchers in your field

- rapid publication on acceptance

- support for research data, including large and complex data types

- gold Open Access which fosters wider collaboration and increased citations

- maximum visibility for your research: over $100 \mathrm{M}$ website views per year

At BMC, research is always in progress.

Learn more biomedcentral.com/submissions 